\title{
Las grandes instituciones cluniacenses his- panas bajo el reinado de Alfonso VI
}

\author{
José-Luis SEnRA \\ Universidad Complutense de Madrid
}

¿Cuál era el paisaje monumental que pudo conocer Alfonso VI de León-Castilla (1073-1109) durante sus casi cuarenta años de reinado? Tradicionalmente se ha considerado éste un periodo de transición cultural, una claudicación del legado hispano-visigodo en pro del galo-romano. Si algo resulta obvio y así ha sido puesto de manifiesto por los principales especialistas que se han ocupado de su gobierno, es la clarividencia a la hora de interpretar el complejo escenario socio-político que le tocó vivir gestionando, bien que con éxito desigual, dos intensas fuerzas de presión como fueron la política gregoriana y la súbita transformación del mundo andalusí de sujeto pasivo a frente de combate. Paradójicamente durante buena parte del siglo pasado el personaje y las circunstancias que le tocó vivir fueron perfilados de modo negativo a través del prisma de la omnipresente y voraz figura de Rodrigo Díaz en su faceta legendaria ${ }^{1}$.

Con todo, es justamente a partir del rol de Alfonso como antihéroe en la trama épica del Cid, como se generó un amplio corpus de propuestas escenográficas que trataron de recrear el entorno de la segunda mitad del siglo XI en la que se desarrollaron aquellos hechos: desde la pintura de historia (La jura de Santa Gadea, de Marcos Hiráldez Acosta, 1864), pasando por el cine (El Cid, de Anthony Mann, 1961) o la novela gráfica (la inconclusa serie El Cid, de Antonio Hernández Palacios, 1971-1973, 1982)2. Con mayor o menor fortuna y sujetos a los conocimientos de la época, cada uno de estos autores se aprovisionó de documentación con objeto de dar credibilidad histórica a diferentes escenas de la vida del monarca acontecidas en escenarios dispares. En el primer caso, el cuadro de la Jura de Santa Gadea, en el interior de una iglesia de tradición hispana (fig. 1)3. Por lo que respecta a la secuen-

1 Una síntesis de la cuestión: A. GAmBrA, “Alfonso VI y el Cid. Reconsideración de un enigma histórico", en Actas del congreso internacional "El Cid, poema e historia" (12-16 julio 1999) (C. Hernández Alonso, coord.), Burgos, 2000, pp. 189-204. Se ha llegado a hablar de una "etapa cidiana de nuestros historiadores y poetas": J.A. Maravall, El concepto de España en la Edad Media, Madrid, 1997 (1954), p. 434.

2 Cualquiera de estas recreaciones presenta significativos anacronismos ya que la finalidad primordial se fundamentaba en insertar la imagen arquetípica del guerrero, heroico, despechado y arrogante con su rey en una caja espacial más o menos verosímil.

3 Sobre este asunto: C. ReYero, Imagen histórica de España (1850-1900), Madrid, 1987, pp. 94-96; C. Reyero, La pintura de historia en España, Madrid, 1989, 64-73. La legendaria Jura de Santa Gadea en la versión de Hiráldez fue muy utilizada en la ilustración de libros de historia de la España medieval incluso en épocas más recientes como es el caso de la cubierta del volumen segundo ('La época medieval') de la emblemática Historia de España de Alfaguara (1973). 


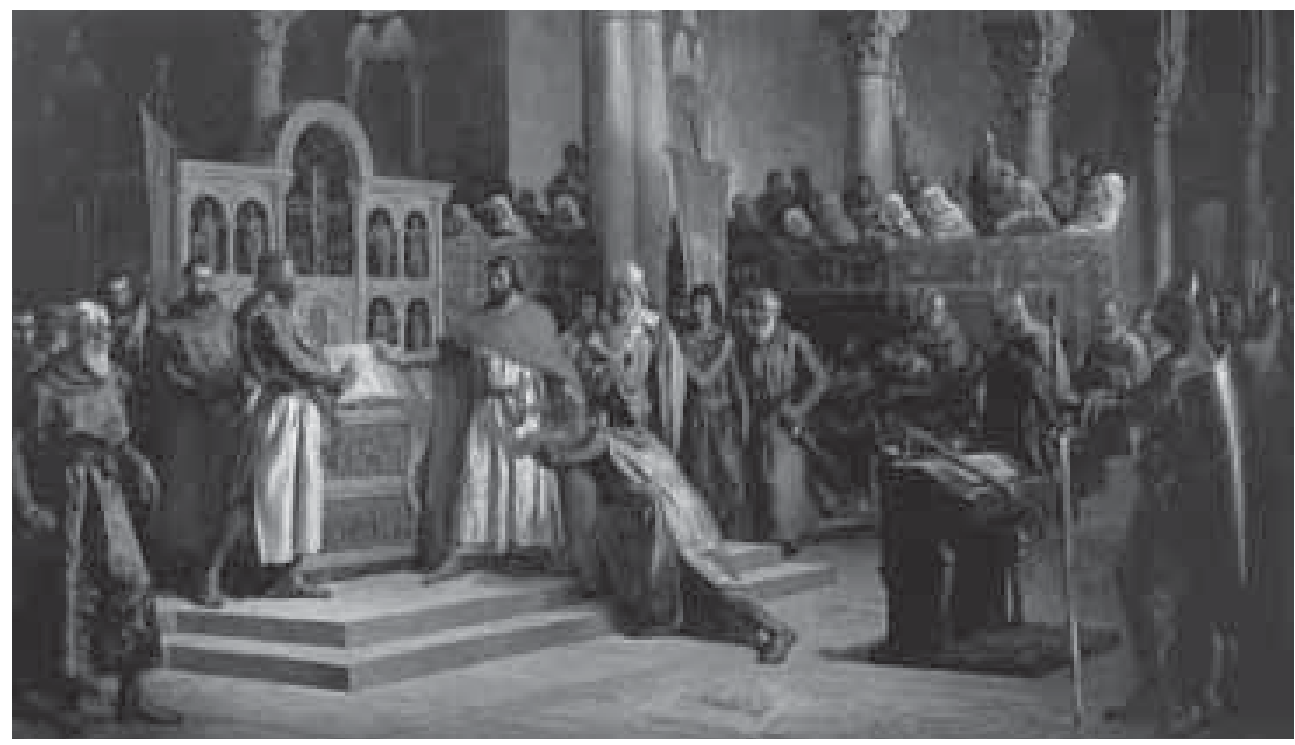

Fig. 1. Jura de Santa Gadea. Marcos Hiráldez Acosta, 1864 (Palacio del Senado, Madrid).

cia narrativa cinematográfica, a través de escenografías arquitectónicas variadas que oscilan entre lo más o menos autóctono (primera escena con la iglesia derruida por una incursión musulmana), lo románico maduro (exterior de la catedral de Burgos) y lo neorrománico (palacio de Fernando I) ${ }^{4}$. En fin, en el relato gráfico, quizá una de las arquitecturas más llamativas sea el panteón de San Isidoro durante la ceremonia de recepción de las reliquias del obispo de Sevilla, en diciembre de 1063, haciéndose eco el autor de lo que a comienzos de los años setenta era casi un axioma: que el panteón pertenecía al reinado de Fernando (fig. 2$)^{5}$. Las grandes lagunas de conocimien-

4 Los decorados, nominados por la Academia en la $34^{\mathrm{a}}$ entrega de los premios Oscar® en Hollywood (el galardón fue obtenido por West Side Story), fueron realizados bajo la dirección artística de Veniero Colasanti y John Moore en los estudios Samuel Bronston de Chamartín (J. GARCíA DE DuEÑAs, "Samuel Bronston. Ascenso y caída de un imperio", Secuencias, 9 (1998), pp. 7-26, esp. 17-18). Ver ficha de la producción en: The American Film Institute Catalog of Motion Pictures Produced in the United States: Feature Films, 1961-1970, University of California Press, 1997 (1976), p. 177. En torno al marco histórico hispano de los años 60-70: J.A. BARRIo BARRIO, "El Cid de Anthony Mann. A través del cine histórico y la Edad Media", en: Historia y cine (J. Uroz Sáez, coord.), Alicante, 1999, pp. 268-305. Sobre los parámetros de la escenografía arquitectónica del cine en su ambientación medieval: J.A. RAmírez, La arquitectura en el cine. Hollywood, la Edad de Oro, Madrid, 1986, pp. 175-178.

5 Desde que en el catálogo monumental de León, Manuel Gómez Moreno sentenciara la contemporaneidad del panteón isidoriano al mecenazgo de Fernando I la cronología de esa estructura quedó establecida como un axioma hasta los años setenta (M. Gómez Moreno, Catálogo monumental de España. Provincia de León, Madrid, 1925, vol. I, p. 182). Por otro lado, teniendo como referente a Harold Foster (El príncipe Valiente, $1937-$ 1971), al igual que en los pintores decimonónicos del género de historia, el celo por la documentación fue uno de los rasgos característicos del trabajo de Antonio Henández Palacios (M. Ayuso y A. LARA, "Comics en España, años 60 y primeros 70. Nuevas publicaciones, nuevos autores”, en Historia de los comics (J. Coma, dir.), Barcelona, 1982, pp. 1037-1042, esp. 1041-1042; J. CoмA, "En el brumoso amanecer de la libertad. El despertar de los comics españoles a la luz naciente de la democracia”, ibíd., pp. 1141-1148, esp. 1143). 
to y la provisionalidad de muchos resultados científicos en un campo tan complejo como el de la Arqueología, la Historia o el de la Historia del Arte de época medieval se ponen de relieve a partir de las diferencias de criterio que presentaría cada uno de los especialistas en esta disciplina ante la eventualidad de achicar cronologías de cara a asesorar en torno a la reconstrucción del paisaje monumental de un determinado y puntual acontecimiento histórico del reinado de Alfonso.

A partir de la breve exposición de una muestra representativa de conjuntos monumentales, la idea que se tratará de hacer valer en esta aportación será la fundamentada en un hecho: la bipolaridad del paisaje monumental que vivió el monarca. Es decir, la renovación de muchas estructuras pero también la supervivencia de muchas otras prerrománicas durante y más

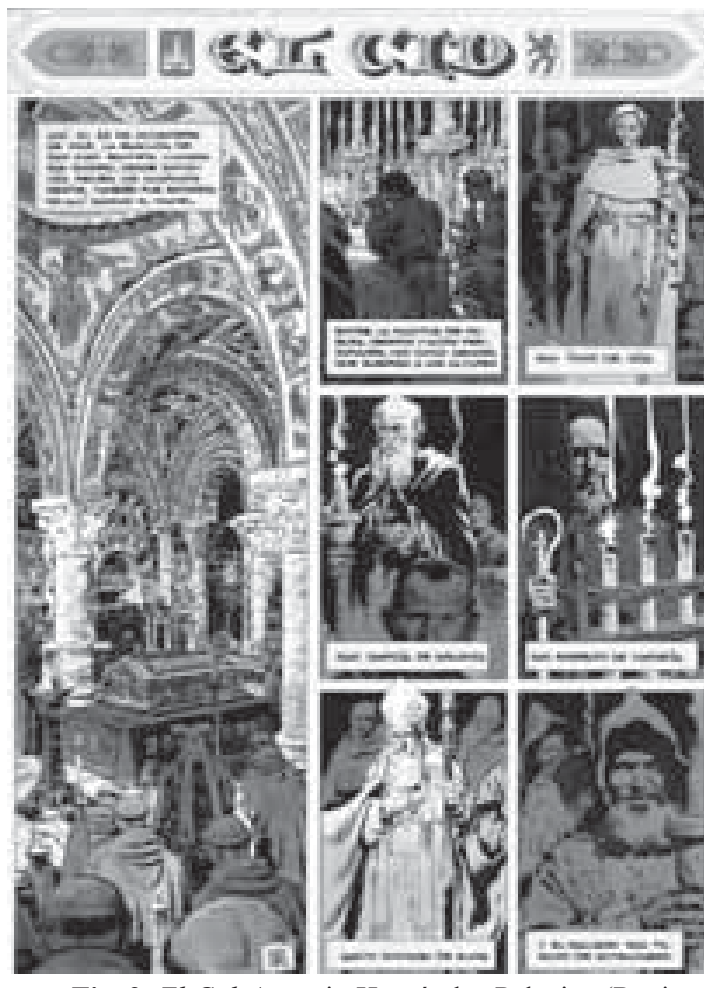

Fig. 2. El Cid. Antonio Hernández Palacios (Revista Trinca, 1971-1973). allá de su reinado. Esto, planteado de manera genérica, no puede sorprender; otra cosa es si concretamos este inmovilismo renovador sobre algunos edificios del tan mitificado siglo XI. Partiendo de la manifiesta reactivación de las principales vías de comunicación, el incremento de las peregrinaciones a Compostela y el cambio de coordenadas geopolíticas de los reinos cristianos del noroeste, sumado al recuerdo más o menos consciente del muy difundido mito del manto de iglesias de Raúl Glaber tras la superación del milenio, se ha tendido a considerar la puesta en marcha de una fiebre constructiva orquestada que, antes del cambio de siglo, redibujó el paisaje arquitectónico castellano-leonés ${ }^{6}$. Obviamente el fenómeno fue harto más complejo .

6 R. Glabri, Historiarum Libri Quinque (J. France, ed.), Oxford, 1989, pp. 114-117. Probablemente Glaber compuso una de las frases más recurrentes de la cronística medieval: en abril de 2007 el entonces candidato a la presidencia de la República Francesa, Nicolas Sarkozy realizando una extrapolación netamente extemporánea, señalaba a propósito de las raíces cristianas de Francia: c'est regarder l'histoire de France telle qu'elle est, et ce «long manteau d'églises» qui recouvre notre pays (Le Figaro, 18 Abril 2007). Sobre algunos de estos excesos nacionalistas: P.J. GeAry, The Myth of Nations: The Medieval Origins of Europe, Princeton, 2002.

Sobre estas coordenadas es explícito el párrafo de Georges Gaillard centrado en la iglesia del monasterio de Silos a partir de la idea de que la dedicada en 1088 fue la llamada iglesia alta: On voit alors partout, à Léon même, à la cathédrale et à Saint-Isidore, à Saint-Jacques de Compostelle, à Sahagún, à Frómista, à Arlanza près de Silos, d'immenses édifices remplacer les édifices de dimensions restreintes qui venaient 
A la hora de considerar los ritmos con los que las diversas instituciones religiosas procedieron a sustituir sus estructuras arquitectónicas conviene desechar, aunque solo sea por falta de testimonios documentales, la simple voluntad de adoptar un léxico constructivo que pudiera adecuarse a la 'ortodoxia' foránea. El fundamento primordial para la sustitución de un edificio oscilaba entre la falta de espacio, la inadecuación litúrgica, el exceso de gastos de mantenimiento de estructuras antiguas y, en el singular marco en el que nos movemos y en estrecha relación con todo ello, la identificación con una nueva cultura eclesiástica. En contra se alzaba el conservadurismo derivado del perenne binomio antigüedadprestigio y la resistencia a hipotecar rentas para sufragar iniciativas siempre muy onerosas. De ningún modo puede ser sensato ningunear el importante papel de la reforma gregoriana y el cambio ritual en los reinos occidentales de la Península Ibérica (León, Galicia, Castilla, Aragón), como tampoco podría serlo considerarlo un brusco hiato.

\section{El papel de los prioratos cluniacenses hispanos en la 'renovación románica'.}

Hace unos años defendí que los principales establecimientos cluniacenses de Tierra de Campos estaban definidos por unas líneas arquitectónicas muy concretas, que cobraban mayor vigor en la definición de sus fachadas occidentales ${ }^{8}$. El énfasis puesto en esta zona, de intensa carga litúrgico-simbólica, alcanzó un desarrollo completamente inédito en las realizaciones autóctonas de los siglos IX a XI, ancladas en la tradición paleocristiana, y sujetas por tanto a una rígida y perseverante horizontalidad. Aunque nos faltan muchos edificios de época románica, desaparecidos entre los siglos XIV y XVIII, es notorio que las iglesias de los prioratos cluniacenses de San Isidoro de Dueñas y de San Zoilo de Carrión de los Condes, junto a Santa María de Nájera, las tres posesiones de Cluny en la Península Ibérica de mayor importancia, estaban sujetas a esta concreta y reglada planificación? ${ }^{9}$.

parfois seulement d'être achevés dans les annés précédentes. L'abbé de Silos, Fortunius, a bien pu participer à cette "fièvre de construction» en agrandissant l'église de son prédécesseur et en construissant l'église supérieure (G. GAILLARD, "L'église et le cloître de Silos. Dates de la construction et de la décoration", Bulletin Monumental, XCI (1932), pp. 39-80, esp. 73). Sobre los argumentos que complican esa opción cronológica ver: J.L. SenRA, "Santo Domingo de Silos: New Interpretive Suggestions for the Medieval Church (10731143)", en Church, State, Vellum and Stone: Essays on Medieval Spain in Honor of John Williams (T. Martin y J. Harris, eds.), Leiden, 2005, pp. 329-372.

8 J.L. SenRa, "Aproximación a los espacios litúrgico - funerarios en Castilla y León: pórticos y galileas", Gesta, XXXVI (1997), pp. 122-144.

9 Los restos arquitectónicos del priorato de Nájera correspondientes a los siglos XI y XII son mínimos y no lo suficientemente representativos para poder elaborar una hipótesis fundamentada sobre la morfología del templo, si bien en el extremo oeste se intuye una carga ideológica notable al abrigar el panteón real. Para este conjunto ver: J.L. SENRA, "Algunas notas sobre la realidad románica del priorato cluniacense de Santa 


\section{San Zoilo de Carrión de los Condes}

Junto a Dueñas y Nájera fue el establecimiento más importante de la red cluniacense hispana. Y a partir de la presencia entre su documentación de un diploma de tanta importancia para los intereses de Cluny como el del censo duplicado de Alfonso, incluso podría decirse que tuvo cierta preeminencia sobre los otros dos ${ }^{10}$. Circunstancialmente formó parte del patrimonio real hasta su entrega por parte de Fernando I de León-Castilla (1037-1065) a uno de sus más notables allegados, el entonces cabeza de la poderosa familia Beni-Gómez, Gómez Díaz (ob. ca. 1058) probablemente no antes de la década de los años cuarenta del siglo $\mathrm{XI}^{11}$. Aunque la falta de documentación no nos permite saber apenas nada sobre los primeros pasos de esta segunda trayectoria del monasterio, lo cierto es que fue redefinido con un estrecho vínculo de familiaridad ${ }^{12}$. Tal reconfiguración trajo consigo el establecimiento de un área de enterramiento contigua a la iglesia cuyo uso por parte de los miembros de este linaje tuvo una extensión temporal que se prolongó más allá del siglo XII.

Aunque en las dos últimas décadas el conocimiento de la iglesia se ha ampliado de forma exponencial, aún quedan muchas incógnitas. Una de las más reseñables es la que atañe a la concreta intervención de Gómez Díaz y su esposa, Teresa Peláez, sobre el conjunto recibido de manos del monarca. Aunque de un documento rubricado por Teresa, ya viuda, y sus hijos en1076 se desprende que la construcción del monasterio había sido concluida tiempo atrás, los restos medievales más antiguos que han ido apareciendo son de clara filiación románica. Y de un románico no compatible con el que pudiera haberse materializado en fechas tan tempranas para cuya orientación nos podría valer la iglesia de San Salvador de Leire, consagrada en $1057^{13}$.

Centrándonos en el análisis de los restos románicos que hasta la fecha tenemos de este importante priorato y a partir tanto de la lectura de paramentos como de la sintonía de la estilística ornamental contextualizada, en principio puede hablarse

María de Nájera en su contexto histórico", en Memoria Artis (Homenaje a la profesora María Dolores Vila Jato), Santiago de Compostela, 2003, tomo I, pp. 123-142.

${ }^{10}$ C.H. Bishro, "El abad Radulfo de Cluny y el prior Humberto de Carrión 'Camerario' de España: tres cartas inéditas de hacia 1174”, Anuario de Estudios Medievales, I (1964), pp. 197-215.

${ }^{11}$ En la tesitura de elegir la acepción de Beni o Banu para el término árabe (ونب), "hijos de", es preferible adoptar la primera ya que la segunda no responde sino a la versión clasicizada usada por los historiadores árabes de lo que tanto en árabe como en romance era Beni Gómez o Bani Gómez, correspondiente a la forma dialectal arábiga, que era la comúnmente usada. Agradezco a Alberto Montaner (Universidad de Zaragoza) esta ajustada puntualización.

12 J. OrLandis, "La elección de sepultura en la España medieval", Archivo de Historia del Derecho Español, XX (1950), pp. 5-49.

${ }_{13}$ Para el comienzo de una dualidad de léxicos constructivos en este tramo cronológico ver: J.L. SenRA, "Algunas notas sobre la realidad románica del priorato cluniacense de Santa María de Nájera en su contexto histórico", pp. 123-142, esp. 127-129. 


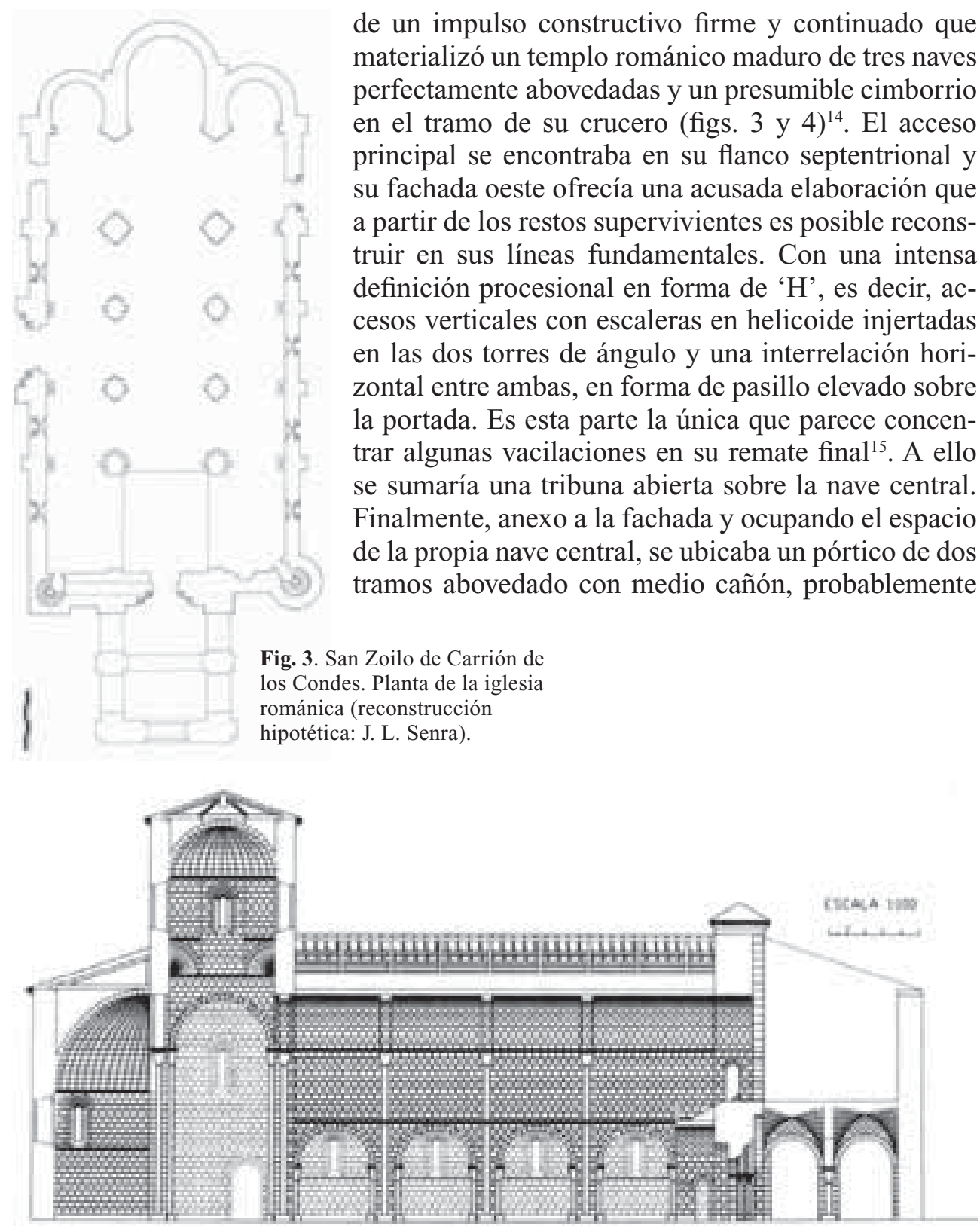

Fig. 4. San Zoilo de Carrión de los Condes. Sección longitudinal de la iglesia románica (reconstrucción hipotética: J. A. Perrino).

14 La definición de las líneas arquitectónicas básicas de la iglesia de San Zoilo puede obtenerse a partir de las concordancias que presentan muchos de sus elementos supervivientes con la iglesia de San Martín.

15 Tales evidencias se concentran en el exterior de la torre, por encima de la altura de la portada. 
de dos niveles. A diferencia de Dueñas, Carrión planteó su torre noroeste de modo más complejo y solidario con la mecánica litúrgica foránea, con objeto de introducir en ella una capilla probablemente dedicada al arcángel san Miguel. El tradicional contenido escatológico de esa fachada se incrementaba con la presencia en ese punto del ya mentado panteón, memoria de la familia condal, en el que a fines del siglo XIII se concentraban más de una decena de sepulturas ${ }^{16}$.

La portada occidental presenta unas dimensiones limitadas debido al condicionamiento que supuso la presencia ya comentada de una estructura porticada anexa de dos niveles. Si bien desde el punto de vista simbólico fue el acceso principal, su intensa carga escatológica reforzada con las sepulturas condales reducía su funcionalidad como umbral para los laicos. Al igual que muchas iglesias cuyo eje Este-Oeste coincidía con la vía de comunicación que transcurría a su vera, la puerta septentrional desempeñó el papel de acceso principal. El programa iconográfico de la puerta oeste, codificado en cuatro capiteles, parece conformar una secuencia de Fe (capitel izquierdo, jamba derecha: Asno de Balaam), Resurrección (capitel izquierdo, jamba izquierda), preludio al fin de los tiempos o salvación a través de los frutos de la palabra de Cristo (capitel derecho, jamba derecha: vendimiadores), o el Mal en una representación genérica (capitel derecho, jamba izquierda: animales monstruosos) ${ }^{17}$.

Del acceso norte poco puede decirse ya que no ha quedado ningún resto visible. Tanto su exacta topografía como su prioridad de uso respecto a la anterior portada fueron mantenidas por la reforma del templo llevada a cabo en el siglo XVII. Fundamentándolo en la intensa presencia de esa tipología en las iglesias románicas de Carrión (Santa María y sobre todo Santiago) y de los alrededores (Moarves de Ojeda), hace un tiempo especulé con la posibilidad de que su principal ornamentación se basara en un friso esculpido con un pantocrátor y un apostolado ${ }^{18}$. De esta manera, habría sido el prototipo del área territorial palentina aunque, obviamente, no podemos rebasar la línea de la hipótesis ya que nos faltan evidencias materiales para poderlo afirmar. Con todo pienso que se trata de una opción interpretativa plausible que quizá con el tiempo, a la luz de nuevos hallazgos, pueda definirse en su justa extensión.

Habitualmente y a partir de su epitafio, la financiación de este edificio ha sido adscrita a la condesa Teresa, como se ha indicado con anterioridad, responsable junto

16 J.L. Senra, “"Mío Cid es de Bivar e nos de los condes de Carrión». Los Banu-Gómez de Carrión a la luz de sus epitafios”, Quintana, 5 (2006), pp. 233-267.

17 El capitel de la vendimia no es de fácil descodificación. Si bien pudiera hacer referencia a la inminencia de la Parusía (Is 63, 2-3; Ap 14, 14-20), ciertamente podría interpretarse asimismo como la parábola del sembrador (Mt 13, 1-23; Mc 4, 1-20; Lc 8, 4-15), mensaje de salvación a través de la correcta recepción del mensaje de Cristo: "Los que reciben la siembra en tierra buena son los que oyen la palabra, la reciben y dan fruto" (Mc 4, 20); "Lo caído en buena tierra son aquellos que, oyendo con corazón generoso y bueno, retienen la palabra y dan fruto por la perseverancia" $(\operatorname{Lc} 8,15)$.

18 J.L. SEnRA, "Nuevos hallazgos románicos en el monasterio de San Zoilo de Carrión de los Condes (Palencia)", Archivo Español de Arte, 293 (2001), pp. 88-95, esp. 94-95. 
a su marido, Gómez Díaz, de la refundación del monasterio a mediados del siglo. Hay pocas dudas en torno a que la estilística ornamental del edificio románico es compatible con el entorno de 1100. Y el óbito de la condesa se consigna en 1093 por lo que esta asociación pudiera ser viable ${ }^{19}$. Sin embargo, dando por hecho la existencia de un edificio previo prerrománico, el epitafio resulta ambiguo a la hora de precisar cuál de los dos fue el financiado por ella: tanto pudiera referirse al edificado hacia 1100 como al construido entre 1050-1060. Y en esta trama una cuestión es de capital importancia: más allá del epitafio, la documentación solo permite atestiguar que la condesa estuvo tras la terminación, la dotación y la consecuente dedicación litúrgica del edificio de mediado el siglo XI dotado con nuevas reliquias hacia $1070^{20}$. Por el contrario no contamos con documentos que permitan asociar la iglesia románica con el 'matronazgo' de Teresa y por ello no podemos realizar de manera rotunda esta coligación. Obviamente ello no descarta la posibilidad. Simplemente, a mi modo de ver, introduce un elemento que pudiéramos definir como disonante en la reconstrucción del proceso crono-constructivo. En un momento en el que la línea divisoria entre lo histórico y lo hagiográfico era extremadamente delgada, realizar propuestas maximalistas sin considerar que la trama asociativa no es sencilla, resultaría simplemente tan irresponsable como poco riguroso ${ }^{21}$. Y en todo caso la desvinculación del edificio románico de la condesa no desplazaría la adscripción cronológica sino en un exiguo tramo temporal: no más allá de las primeras décadas del siglo XII. Por otro lado, si el epígrafe perteneciera al momento de la monumentalización románica como parece,

19 Aecclesia ponten peregrinis optima tecta (J.L. SENRA, “«Mío Cid es de Bivar ...”, p. 241). Esta asociación fue insertada en la lauda sepulcral que por el contenido y la epigrafía (mezcla de rasgos visigóticos con romanos) parece pertenecer a las primeras décadas del siglo XII. Agradezco a José Antonio Fernández Flórez (Universidad de Burgos) su asesoría en la ubicación cronológica del epígrafe. El mismo ligazón de la iglesia con la condesa Teresa se encuentra hacia 1135, es decir, cuarenta años después de su muerte, en la obra de Radulfo, el hagiógrafo de san Zoilo: le responsabiliza de la sustitución de la inicial ecclesiam paruissima por otra lapidibus opere mirifico edificata est que habría dotado con variado tesoro litúrgico (C.M. REGLERO DE LA FuENTE, Cluny en España. Los prioratos de la provincia y sus redes sociales (1073 - ca. 1270), León, 2008, p. 244, n. 42).

20 J.A. PÉRez CeladA, Documentación del monasterio de San Zoilo de Carrión (1047-1300), Salamanca, 1986, doc. 8, pp. 19-21. Bajo este asunto subyace una importante cuestión: muchas veces por fallecimiento del marido, más expuesto tanto en función de su inferior longevidad biológica como, sobre todo, por sus riesgos en el ejercicio de la guerra, eran las mujeres las que concluían su obra. En este contexto podrían traerse los ejemplos de García Sánchez (1035-1054) en Santa María de Nájera, construcción muy probablemente rematada por su esposa Estefanía de Foix con la dedicación de 1056 (J.L. SENRA, "Algunas notas sobre la realidad románica del priorato cluniacense de Santa María de Nájera en su contexto histórico”, pp. 123-142, esp. 125129) o de Fernando I y Sancha con San Isidoro de León, completando ésta última la obra una vez fallecido aquél en diciembre de 1065 [Sancia Regina deo dicata peregit]. Ver inscripción en: T. MarTin, Queen as King. Politics and Architectural Propaganda in Twelfth-Century Spain, Leiden, 2006, p. 46.

${ }^{21}$ La vinculación del edificio románico con la condesa pasa porque la construcción de éste estuviera en marcha antes de 1093, es decir, menos de tres décadas después de haber financiado la edificación de otro. ¿Apoyaría el derribo de un monasterio iniciado por iniciativa conjunta con su marido y concluido por ella misma y sus hijos años más tarde? Hay que tener en cuenta además que, si bien carecemos de su testamento, tras la muerte de la condesa en 1093, buena parte de sus bienes debieron pasar a engrosar los del priorato cluniacense. Tal saneamiento de rentas posibilitaba una nueva construcción. 
es plausible que los monjes cluniacenses procedieran a ejecutarlo y redactarlo de modo retrospectivo, a modo de exemplum piadoso, al son de la nueva y extraordinaria estructura románica que hoy tan solo podemos intuir a través de algunos pocos pero significativos restos. Hace tiempo realicé una ecuación estilística entre los capiteles de la portada occidental y la lauda de Alfonso Pérez (ob. 1093) ${ }^{22}$. La equidistancia es obvia y, como dejé dicho, una separación de dos o tres quinquenios entre ambas obras dada la pervivencia y expansión de talleres y estilos en segmentos cronológicos más amplios no perturba en absoluto la propuesta. Sobre este último asunto se insistirá más adelante a propósito de otro edificio.

\section{San Isidoro de Dueñas}

La importancia de este monasterio durante la Alta Edad Media fue notablemente superior a la de San Zoilo de Carrión. Fundado en el entorno del año 900 por el rey Alfonso III, en 935 una solemne dedicación protagonizada por ocho obispos y ocho abades presididos por su sucesor, Ramiro II, culminaba un nuevo edificio que debemos considerar de valores muy notables ${ }^{23}$. Su estrecha vinculación a la monarquía, denominador común con el cercano monasterio de Sahagún a cuyas calidades me referiré más adelante, hacen posible considerar la importancia de su templo prerrománico aún sin contar con resto alguno de su fábrica. Y con el coadyuvante de haberse conservado un conjunto de fuentes documentales que resulta extraordinariamente corta y muda en lo que se refiere a datos constructivos del periodo comprendido entre los siglos X a comienzos del XIII ${ }^{24}$.

En el siglo XVII se procedió a una reforma de la iglesia románica acusadamente conservadora, gracias a lo cual ha llegado hasta nuestros días muy buena parte de la osamenta arquitectónica románica. A través de los restos ornamentales conservados tanto en su interior (básicamente basas de columnas en la cabecera) como en su exterior (portada occidental) se puede considerar que el edificio del siglo $\mathrm{X}$ en época románica fue sustituido y que, probablemente en la segunda mitad del siglo

22 J.L. SENRA, "La portada occidental recientemente descubierta en el monasterio de San Zoilo de Carrión de los Condes", Archivo Español de Arte, LXVII (1994), pp. 59-73.

${ }^{23}$ A partir de que Gómez Moreno estableciera que ese acto litúrgico de 935 afectó a la iglesia de Sahagún (M. Gómez Moreno, Iglesias mozárabes. Arte español de los siglos IX al XI, Madrid, 1919, p. 204) se ha repetido una vez y otra que la inauguración de la iglesia de los Santos Facundo y Primitivo se produjo en ese año cuando realmente afectó al templo de San Isidoro de Dueñas. Sobre esta cuestión: P. HenRIET, "L'idéologie de guerre sainte dans le Haut Moyen Âge Hispanique", en Francia 29/1. Forschungen zur Westeuropäischen Geschichte, 29/1 (2002), pp. 205-206, n. 186). También: C. ReGLeRo de LA FueNTE, El monasterio de San Isidoro de Dueñas en la Edad Media. Un priorato cluniacense hispano (911-1478). Estudio y colección documental, León, 2005, doc. 7, pp. 76, 299-301.

${ }^{24}$ Ibid., pp. 285-447. 
XII, esta estructura amplió su cabecera introduciendo un transepto. Sin embargo es la fachada occidental junto a su portada historiada la que, por el tema que aquí tratamos, interesa resaltar.

Como he señalado, estamos desasistidos de fuentes directas o indirectas para considerar con exactitud la cronología de esta zona románica, la más antigua del transformado conjunto románico que ha sobrevivido. El único terminus post quem es en exceso genérico: la entrega del monasterio a la orden de Cluny en 1073. La otra coordenada cronológica se centra en la estilística ornamental de la puerta, con la relatividad que esta vía frecuentemente conlleva (cestas de capiteles con volutas muy desarrolladas y ábacos con bolas). Desde el punto de vista estructural, presenta una articulación muy semejante a la que puede constatarse en la de San Zoilo y San Martín de Frómista: tipo y proporciones de arcos, basas, cestas y zócalos. Por su parte, la iconografía que se injertó en ella es de fácil descodificación: la avaricia y la lujuria, dos de los vicios más intensamente martilleados por la ortodoxia gregoriana, igualmente presentes en la portada norte de Frómista y en su interior (fig. 6).

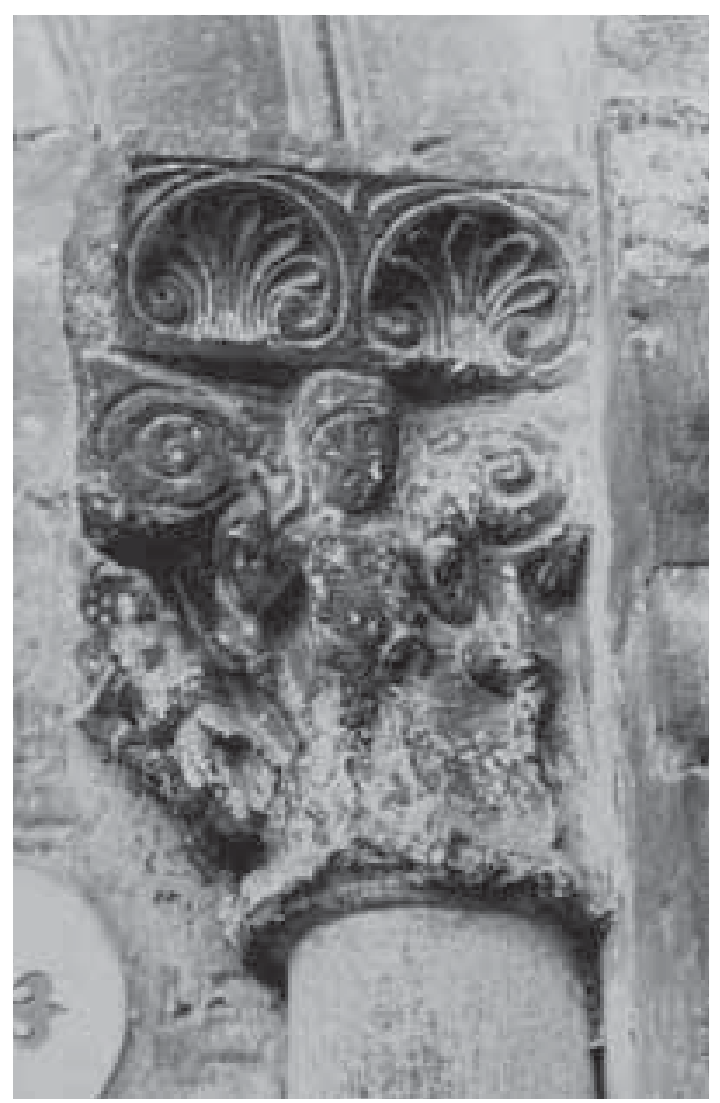

Fig. 6. San Isidoro de Dueñas. Portada occidental: capitel de la lujuria (Foto: J. L. Senra).
La organización espacial de la iglesia románica de Dueñas era parcialmente diferente a la de San Zoilo. Mientras que allí los dos accesos principales se encontraban ubicados en la nave septentrional y en el flanco occidental, en Dueñas todo hace suponer que ambos se fundían en el de poniente, en línea con la vía de comunicación principal. Pero éste, al igual que aquél de Carrión, se elaboraba mediante una fachada con dos torres de ángulo y un pórtico occidental. Los vestigios de éste son claramente perceptibles en el paramento del hastial lo que unido a la singular potencia del muro en el que se engarzaba -a partir de la existencia en San Zoilo, muy susceptible de haber abrigado un pasillo abovedado-, permite considerar la homogeneidad de proyectos (fig. 7). En definitiva: dos diseños de categórica carga litúrgica y de dirección indiscutiblemente cluniacense. 


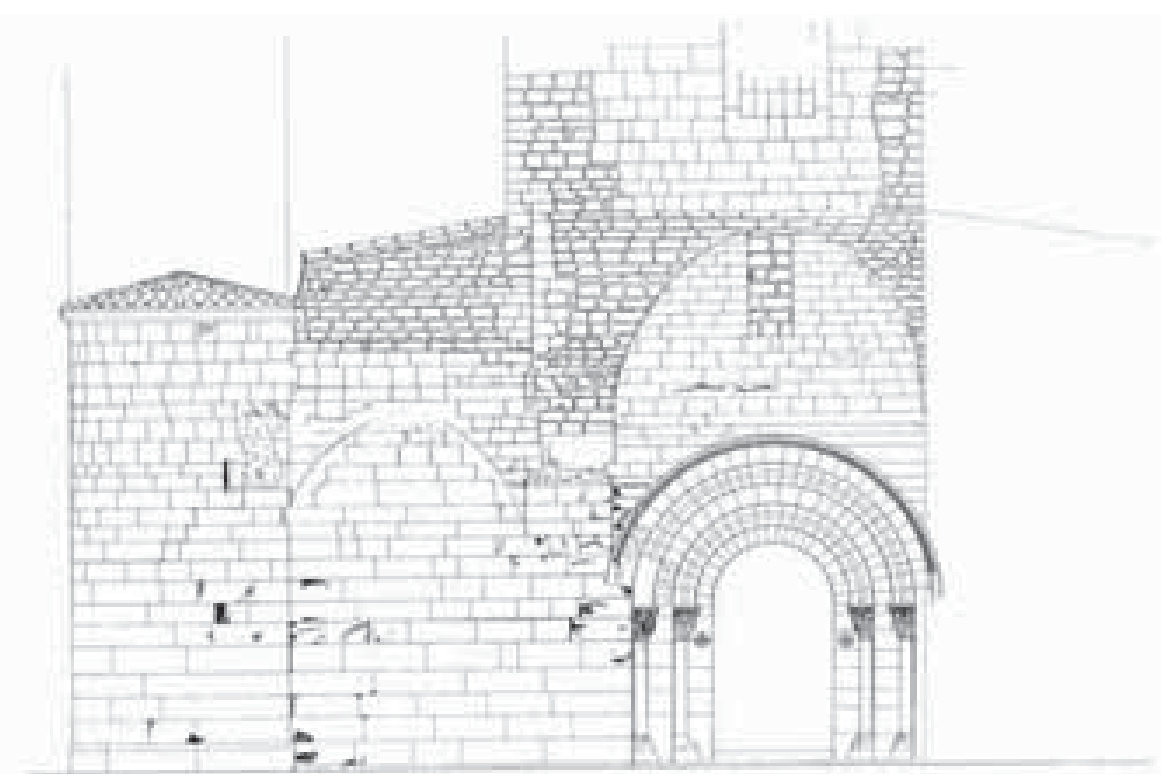

Fig. 7. San Isidoro de Dueñas. Fachada occidental (J. L. Senra).

\section{San Martín de Frómista}

En la iglesia de San Martín se encuentra un reflejo nítido de la fórmula arquitectónica presente en las dos instituciones cluniacenses anteriores. La pregunta de forzosa formulación es: ¿Estamos ante un edificio construido una vez que la institución fue entregada a Cluny en 1118? O dicho de otro modo: ¿Cuándo se renueva la iglesia financiada antes de 1066 por Mayor, la viuda de Sancho III y madre de Fernando I? Existen significativos argumentos estilístico-iconográficos, concentrados en la cabecera del edificio, que apuestan por establecer el cambio de fábrica hacia $1090^{25}$. Esta ubicación cronológica cuenta con la asistencia de la proximidad del modelo de la plástica grecorromana adoptada en el sepulcro de Husillos (conservado a $25 \mathrm{~km}$ al Sur de Frómista), presente en la catedral Jaca sobre la que también habría irradiado. La catedral aragonesa sí cuenta con datos cronológicos documentales ciertos: el edificio se estaba construyendo en las dos últimas décadas del siglo XI. Esta relación triangular definió tanto las fechas de

25 Los argumentos a favor de la cronología de hacia 1090 fueron todos ellos formulados en un excepcional y pionero trabajo por Serafín Moralejo, principal contribuidor a que se acabara con la asociación del edificio con el testamento de Mayor (1066): S. Moralejo Álvarez, "Sobre la formación del estilo escultórico de Frómista y Jaca", en Actas del XXIII Congreso Internacional de Historia del Arte. Granada 1973, Granada, 1976, volumen I, pp. 427-434. Más recientemente: F. Prado Vilar, "Saevum Facinus: estilo, genealogía y sacrificio en el arte románico español”, Goya, 324 (2008), pp. 173-199; S. TRINKS, "Skulpturen in Serie: Antike als Produktivkraft im Spanien des 11. Jahrhunderts", en Konzepte von Produktivität im Wandel vom Mittelalter in die Frühe Neuzeit (C. Laude y G. Heß, eds.), Berlín, 2008, pp. 181-205. 
Frómista como, a partir de su proximidad con Husillos, una presumible anticipación sobre Jaca.

Sin embargo existen cuestiones que a mi modo de ver no permiten dejar cerrada la asociación de la iglesia de San Martín con el entorno de 1090. Hay que partir de un hecho cierto: el vacío documental (institucional) del monasterio en ese dinámico periodo. ¿Quiénes fueron sus abades entre 1066 y 1118 ? En Frómista nos encontramos con una inhabitual circunstancia respecto a cualquiera de los monasterios más pujantes de León-Castilla: más de cincuenta años de silencio sobre este particular asunto ${ }^{26}$. La cuestión se hace más extraña si cabe cuando se observa que este vacío también se hace extensivo a la documentación indirecta, es decir, a aquella ajena a Frómista en la que podría constar como confirmante su abad. Siempre es posible la pérdida de diplomas. Pero ¿también en los cartularios ajenos? Un edificio paradigmático, y no hay duda de que Frómista lo es, suele tener tras de sí la figura de un importante e influyente administrador. En definitiva, del abad o abades que rigieron el monasterio de San Martín en la segunda mitad del siglo XI no tenemos registro documental alguno. ¿Un síntoma del poco relieve de la institución hasta su cambio de rol como priorato cluniacense?

Pero no es este el único elemento disonante. La cronología de Frómista se ha trazado a partir de una mirada, a mi modo de ver, focalizada con intensidad excluyente en la escultura de la cabecera, concretamente en dos capiteles y unos cuantos canecillos de esa misma zona. Por el contrario apenas se ha afrontado la significación de su arquitectura y de sus singulares características en el contexto de fines del siglo XI. Hay preguntas inevitables: ¿Qué edificio de ese periodo presenta una confluencia de soluciones resueltas de modo tan maduro, eficaz y rotundo? Me refiero a un abovedamiento completo, una resuelta tipología de cimborrio poligonal, un derroche de capiteles historiados en su interior y sobre todo un inmenso despliegue exterior de escultura monumental en cornisas que se adjetiva incluso en cada una de sus ventanas. Una mirada por las iglesias monásticas de su área geopolítica, todas ellas pertenecientes a instituciones religiosas de mucha mayor importancia, no permite parangón. En ellas se observa un románico notablemente menos elaborado en el que podemos encontrar algunos elementos pero de ningún modo ese conjunto de sincronizada perfección (fig. 8). Para obtener un dominio completo en cada uno de sus frentes la arquitectura precisa de un rodaje en el tiempo: a mi modo de ver la horquilla cronológica de finales del siglo XI se hace precoz para ello.

El asunto se hace más llamativo cuando se afronta la singular configuración de su fachada occidental cuyo primitivo estado era bien diferente al actual, inventado

26 Ni siquiera en su testamento (1066) la otorgante, la reina-madre Mayor, se refiere directamente a un abad de Frómista. Solo quedaría identificarlo con el nominal catalán abbas Miro, testis que en la segunda columna rubrica el documento (J.A. PÉREz CELADA, Documentación del monasterio de San Zoilo de Carrión (1047-1300), doc. 4, p. 13). Sobre la expansión de monjes catalanes en León a mediados del siglo XI: C.J. BISHKO, "Fernando I y los orígenes de la alianza castellano-leonesa con Cluny", Cuadernos de Historia de España, XLVII-XLVIII (1968), pp. 48-76. 


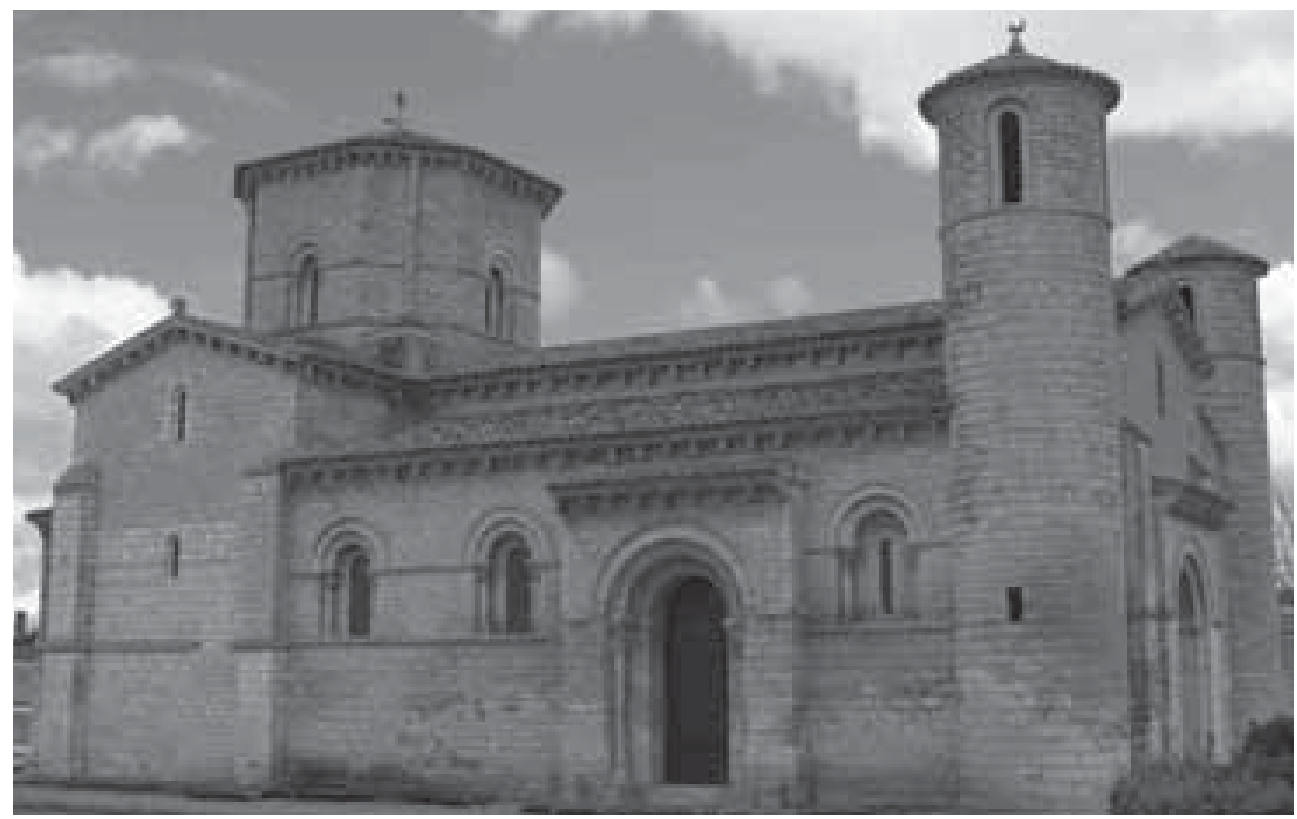

Fig. 8. San Martín de Frómista. Vista general lado norte (Foto: J. L. Senra).

en la restauración realizada entre 1895-1904. El muro de cierre, notablemente más grueso en origen, era muy susceptible de haber albergado un pasillo alto de comunicación entre las dos torres. Junto a ello, las evidencias en el paramento de arcos de arranque hacia occidente recogidas por el arquitecto-restaurador posibilitan hablar de una tipología de fachada semejante a las de Carrión y Dueñas (fig. 9) ${ }^{27}$. Es en extremo frecuente que las instituciones sujetas a otras de mayor entidad no solo asuman sus concretas directrices espirituales sino que, a la hora de renovar sus estructuras, tiendan a mimetizar alguno de los elementos constitutivos o relevantes de aquellas. Más aún cuando se trata de zonas de alta carga litúrgica. Y todavía más cuando atañe a los prioratos cluniacenses, plegados a unas coordenadas litúrgicas muy específicas. Desde mediados del siglo XI el territorio de Borgoña, área territorial primigenia de la orden, ofrece un buen número de ejemplos de la recepción mimética de los bloques occidentales a partir del edificio madre cuya galilea fue añadida por el abad Odilón (ca. 1035) en respuesta a una intensificación litúrgica de signo escatológico ${ }^{28}$. ¿Tendríamos que pensar que la institución que recepciona el prototipo de bloque occidental en Tierra de Campos fue Frómista a la que se subyugarían San Zoilo y Dueñas? Personalmente no lo creo.

27 Sobre este asunto más ampliamente: J.L. SENRA, "La realidad material de la iglesia de San Martín de Frómista en el siglo XII: de 1066 a 1904”, en San Martín de Frómista ¿paradigma o historicismo?, Santander, 2005, pp. 37-68, esp. 39-49.

${ }_{28}$ K. KRÜGER, Die romanischen Westbauten in Burgund und Cluny. Untersuchungen zur Funktion einer Bauform, Berlín, 2003, pp. 237-261. 


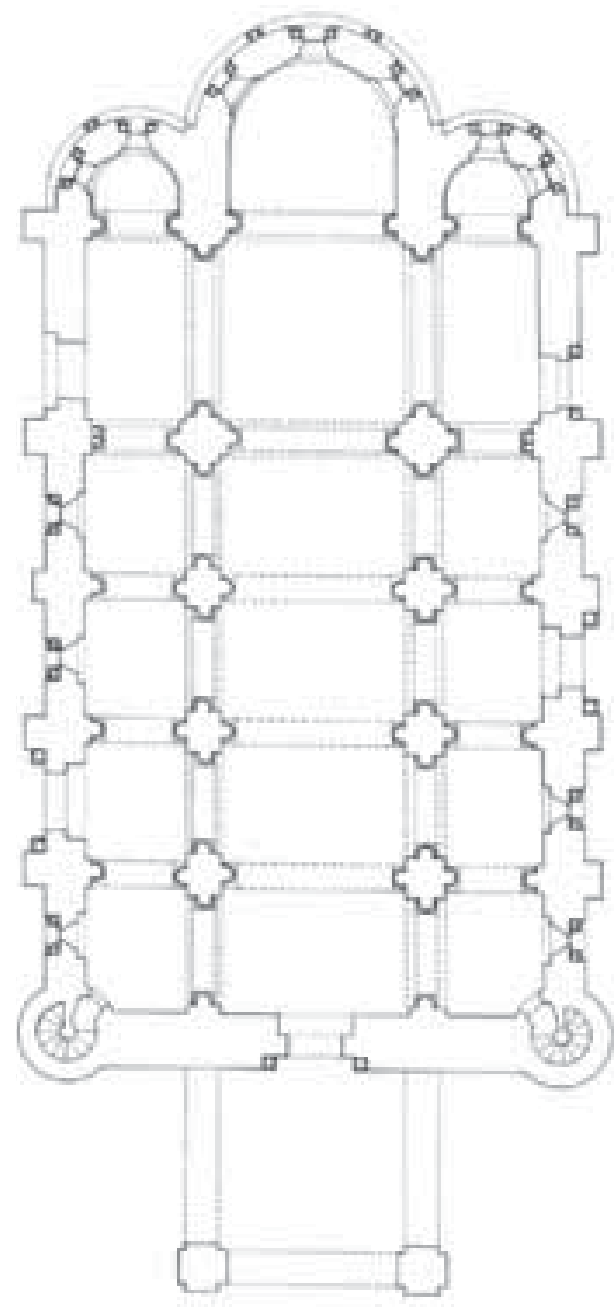

Fig. 9. San Martín de Frómista. Planta de la iglesia (reconstrucción hipotética: J. L. Senra).
Otro aspecto que merece ser comentado es el de la iconografía del templo en el que en mi opinión puede reconstruirse un programa en muy alto grado centrado en la confrontación armada y la consiguiente reconciliación con claras reminiscencias a los movimientos que surgieron en la Francia de los siglos X y XI conocidos como la Paz o Tregua de Dios (figs. 10-12). Aunque esta iconografía pudiera referirse a preocupaciones universales de los prelados entre las que la violencia cobraba particular relevancia, la aparición de estas imágenes en Frómista encuentra un singular acomodo como reflejo de la crítica coyuntura acontecida entre 1109 y 1117 . Es decir, en los hechos ocurridos entre la muerte de Alfonso VI y la celebración del Concilio de Burgos (1117) en el que un acto penitencial realizado en la catedral sirvió de colofón a un largo y desestabilizante conflicto. Como he indicado en otros trabajos a modo de hipótesis, considero que en la iconografía de San Martín de Frómista cristaliza la memoria de esos hechos trágicos que asolaron el reino de León-Castilla siendo la Tierra de Campos además de la geografía de San Zoilo de Carrión y de San Martín de Frómista, el principal núcleo del conflicto ya que se convirtió en la línea divisoria de los territorios dominados por la reina Urraca y Alfonso I de Aragón ${ }^{29}$. En este punto es preciso volver a recordar que la donación de Frómista a Cluny se produjo en 1118. A mi modo

\footnotetext{
29 Sobre esta coyuntura: B.F. ReILly, The Kingdom of León-Castilla under Queen Urraca: 1109-1126, Princeton, 1982, pp. 45-86. Una síntesis de esta interpretación en: J.L. SENRA, “Architecture et décor dans le contexte de la colonisation clunisienne des royaumes septentrionaux de la péninsule ibérique", en Hauts lieux romans dans le sud de l'Europe (XI'-XIIe siècles), Cahors, 2008, pp. 11-70, esp. 53-66. Más ampliamente: "Rebellion, Reconciliation, and a Romanesque Church in León-Castile (ca.1109-1120)", Speculum (en prensa).
} 


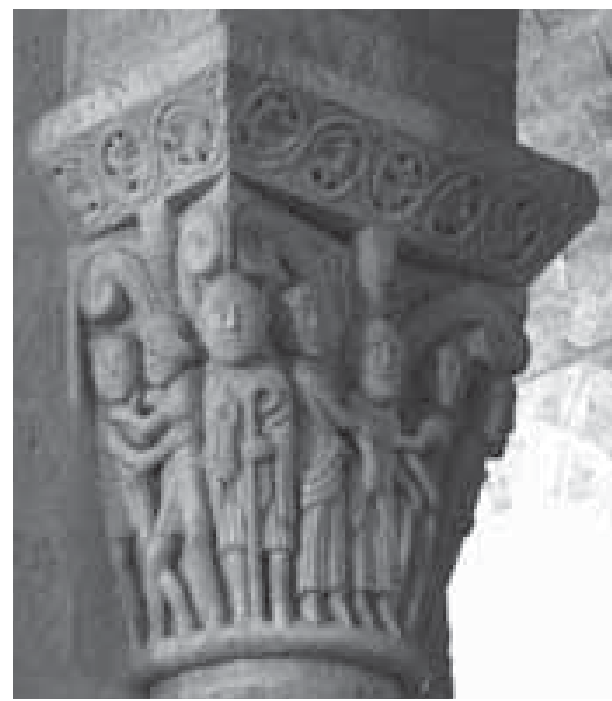

Fig. 10. San Martín de Frómista. Capitel interior: ¿Concilio de Burgos? (Foto: J. L. Senra).

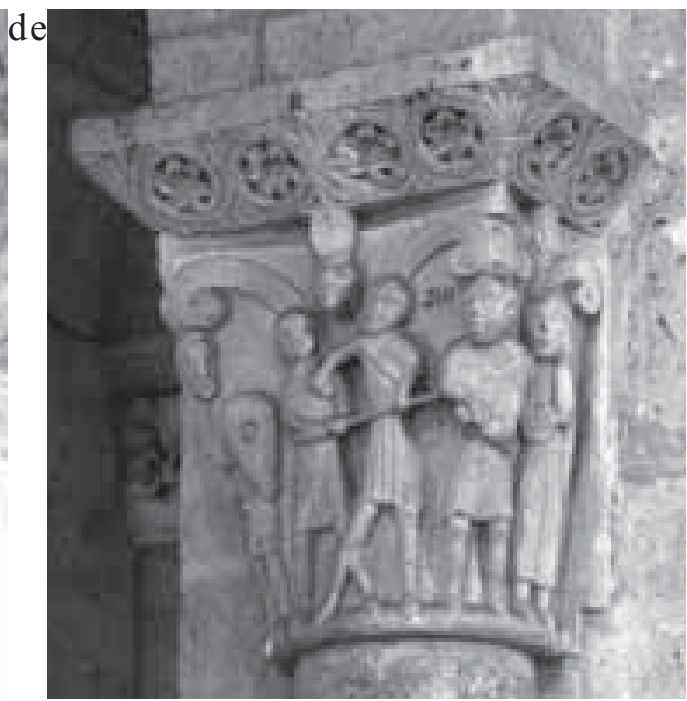

Fig. 11. San Martín de Frómista. Capitel interior: escena de violencia (Foto: J. L. Senra).

ver, uno de los capiteles del intercolumnio de la nave de la epístola -el contiguo al tramo correspondiente a la puerta de salida a la clausura- recogería el acto penitencial realizado en la catedral burgalesa bajo dictado del arzobispo de Toledo, Bernardo (1086-1124), a través del cual se sujetaría a los burgueses rebeldes representados por el sedicioso conde aragonés Beltrán de Risnel (ob. 1134) [fig. 10] $]^{30}$.

Por otro lado, una mirada al resto de la escultura permite comprobar los muchos artesanos allí presentes, síntoma de la premura con la que se levantó el edificio. Negar el impacto del sepulcro de Husillos sobre el escultor antiquizante que trabajó en Frómista sería algo poco cabal. Pero dudar del binomio 'distancia geográfica del sepulcro - década de los años noventa' para situar las obras de Frómista, no me parece en absoluto desorbitado. La huella de Husillos se expandió en un amplio elenco de obras lo que puede hablarnos de la longevidad de un estilo (Jaca, Frómista, León, Compostela). A partir de la constitución familiar de muchos de estos grupos de artesanos, de su consabida itinerancia de unos centros a otros, así como de las arrai-

30 La Primera crónica anónima de Sahagún describe este acto penitencial: "Entonçes determinaron, según la sentencia del arçobispo [de Toledo Bernardo], que ellos [los burgueses] primeramente satisficiesen al abad [de Sahagún], beniendo los descalços e el medio cuerpo desnudo, trayentes en las manos derechas minbres, e conociendo ser en gran culpa por la maldad e mentira que avían fecho he dicho. E por quanto esta satisfaçion non se podía façer en el sínodo por la muchedumbre e ruido de los hombres que en el concilio estaban mui espesos, de todo el convento fueron asinados dos obispos, conbiene a saber: el benerable Hugo de Portugal [1110-1136], e Pascual, de honrrada bida, obispo de Burgos [1114-1118], e Beltrán, conde de Carrión, los quales avían de haçer la execuçión de lo sobredicho" (Crónicas anónimas de Sahagún (A. Ubieto Arteta, ed.), pp. 128-129). 


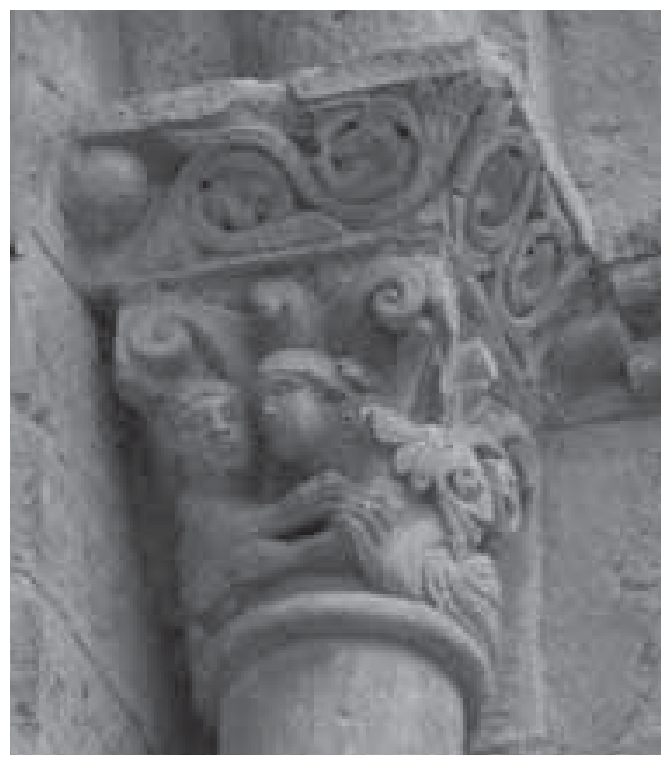

Fig. 12. San Martín de Frómista. Capitel ventana exterior ábside central: escena de reconciliación (Foto: J. L. Senra).

gadas inercias estilísticas de los talleres y de su expansión en el tiempo, no me parecen en absoluto concluyentes las razones expuestas hasta la fecha para situar al autor de la escultura oriental de Frómista en la década de los noventa del siglo $\mathrm{XI}^{31}$.

Con los conocimientos que tenemos en la actualidad, ¿qué es más sensato priorizar?: ¿el estilo escultórico de algunos de los ejemplares de la cabecera o bien la tipología arquitectónica de un edificio estrechamente semejante a Dueñas y a San Zoilo, ambos dos cluniacenses? El monasterio de San Martín fue una iniciativa pía de la abuela paterna de Alfonso VI: probablemente de haberse enterrado allí, algo por otro lado en abierto conflicto con el protocolo del momento y de hecho se inhumó en el monasterio de Oña, una de las principales sedes de su linaje castellano, junto a su marido Sancho III, la suerte del monasterio probablemente hubiera sido otra. Y sin embargo a mi modo de ver el conjunto erigido por la reina-madre, al igual que tantos otros, tuvo una trayectoria más o menos lánguida, sobrevivió a su nieto en el estado prerrománico original y su renovación aún tuvo que esperar una década a la desaparición de éste.

\section{Un caso aparte: el monasterio de los Santos Facundo y Primitivo de Sahagún ${ }^{32}$}

31 Otras geografías pueden servir de ejemplos ilustrativos: la escultura del área gascona con talleres como la cabecera de Saint-Sernin de Toulouse o el claustro de Moissac manifiestan una considerable irradiación de fórmulas y modelos entre 1080 y las primeras décadas del siglo XII. Una síntesis de esta koiné: M. Durliat, La sculpture romane de la route de Saint-Jacques, Mont-de-Marsan, 1990). En Borgoña la irradiación del estilo presente en la tercera iglesia de Cluny se detecta entre fines del XI y mediados del XII con soluciones en ocasiones poco alteradas. Una interpretación de este marco: E. Armi, Masons and Sculptors in Romanesque Burgundy. The New Aesthetic of Cluny III, Pennsylvania, 1983, 2 vols.

32 Parte del análisis de la iglesia prerrománica de Sahagún y del bloque occidental con acceso a ella ha sido extraído de: J.L. SENRA, "En torno a un espacio de evocación: las Res Gesta Domini Adefonsi y la iglesia monástica de Sahagún", en Construcción y representación del poder regio en Castilla (1065-1252), Publicaciones de la Universidad de Valencia, 2011, pp. 243-293. Una síntesis del asunto también en: J.L. SENRA, “Tournus et Sahagún: une connexion architectonique et institutionnelle à la fin du XI' siècle?", Bulletin du Centre d'Études Médiévales, 15 (2011), pp. 267-281. 
Como es sobradamente conocido, el monasterio de Sahagún fue el espacio monumental más próximo a Alfonso VI como demuestra el hecho de que, por voluntad propia, desde 1080 -pocos meses después del inicio de la reforma cluniacense sobre la institución y ya unido a su segunda esposa, Constanza de Borgoña- se convirtiera en el lugar de su enterramiento ${ }^{33}$. Se trataba de una de las instituciones religiosas decanas del reino leonés y con un superávit de prestigio a partir de su fundación real y de la subsiguiente protección tanto de la monarquía como de poderosas familias del territorio ${ }^{34}$. Como pone de relieve la nutrida documentación conservada, el periodo alfonsino se caracterizó por capitalizar una segunda época de esplendor después de la inicial, acontecida desde su fundación a fines del siglo IX, y durante la primera mitad del $\mathrm{X}^{35}$. Las fuentes documentales del monasterio pertenecientes a esa cronología son obstinadas a la hora de categorizar el edificio financiado por Alfonso III como una obra excelsa tanto en su volumen como en su ornamentación (mire magnitudinis). Y los restos conservados, fundamentalmente capiteles, muestran la correlación respecto a estos adjetivos (fig. 13). Contamos con indicios suficientes para considerar que esta estructura, sujeta a diversas reparaciones algunas de mayor enjundia como la que debió llevarse a término tras la razia de al-Mansur en 997, sobrevivió al transcurso del siglo XI.

Hay al menos tres documentos que permiten afirmar esta longevidad: la Primera Crónica Anónima, obra escrita hacia $1118-1120$ por un

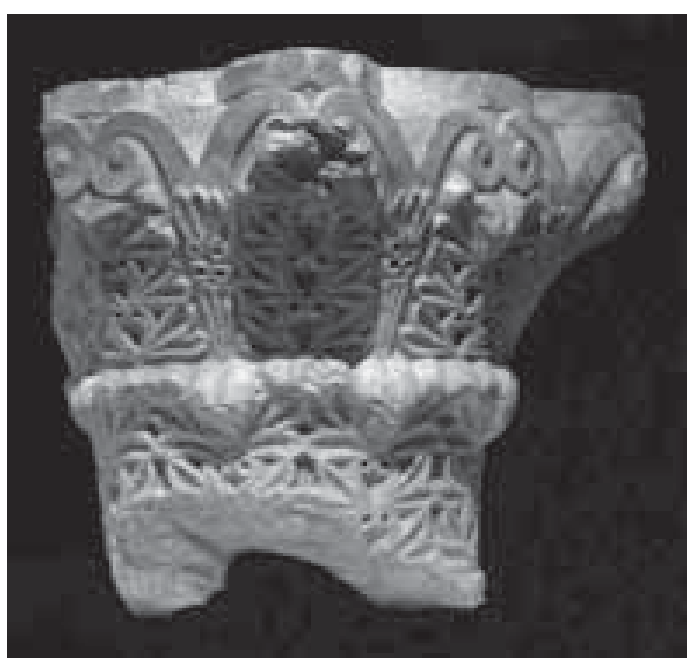

Fig. 13. Santos Facundo y Primitivo de Sahagún. Capitel siglo X. Museo de León (Foto: J. L. Senra).

33 Ver documento en: M. Herrero de la Fuente, Colección diplomática del monasterio de Sahagún (857-1230). III-1073-1109, Madrid, 1988, doc. 786, pp. 76-79. Como se sabe Sahagún solo tuvo una efímera subordinación institucional a Cluny (1132) siendo un monasterio, eso sí, reformado según las coordenadas cluniacenses. Sobre esta reforma: C.M. REgLERo DE LA FuEnTE, "La primera reforma cluniacense de Sahagún, el Concilio de Burgos y la crisis de 1080: revisión cronológica y desarrollo", en Monarquía y sociedad en el reino de León. De Alfonso III a Alfonso VII (Congreso Internacional, León 25-28 de octubre de 2006), León, 2007, tomo II, pp. 689-732.

${ }^{34}$ La familia Alfonso, vinculada a las tenencias de Cea y Grajal, fue la más relevante de cuantas se vincularon al monasterio. Sobre este linaje: P. Martínez Sopena, "Parentesco y poder en León durante el siglo XI; la 'casata' de Alfonso Díaz”, Studia Historica. Historia Medieval, 5 (1987), pp. 33-88; M. TorRES SEVILla, Linajes nobiliarios de León y Castilla (Siglos IX-XIII), Valladolid, 1999, pp. 274-282.

35 Entre 1078-1100 Sahagún recibió treinta y una iglesias y monasterios. Es significativo que en todo el siglo XII solo quince iglesias se sumaran al señorío monástico (J. ORLANDIS, "Reforma eclesiástica en los siglos XI y XII", p. 335). 
monje anónimo del monasterio, el Códice Calixtino, tradicionalmente datado en los años treinta del mismo siglo XII, y finalmente, un diploma perteneciente a los fondos del monasterio fechado en el año 1213. El monje anónimo de la Primera Crónica omite dato alguno sobre la sustitución del viejo edificio o en torno a la realización de trabajos de construcción. Por contra indica que Alfonso III hizo edificar la iglesia como "hasta ahora está"36. Por su parte el Calixtino (IV, 8) ofrece un dato indirecto sobre el templo: a la hora de referirse al apócrifo hispanus iter de Carlomagno, responsabiliza al emperador franco de ordenar y sufragar la construcción de la iglesia del monasterio de Sahagún algo para cuya veraz asociación era preciso el aspecto vetusto del edificio ${ }^{37}$. En fin, el documento de 1213 registra el traslado de los restos de los mártires Facundo y Primitivo de la iglesia vieja a la nueva (de ueteri ecclesia ad nouam) ${ }^{38}$. A mi modo de ver, es muy probable que en él se constatara la conclusión de la parte oriental y de una buena parte del cuerpo de naves de la nueva iglesia románica, momento en el que se hizo posible derribar la prerrománica y trasladar las reliquias de un edificio al otro. Obvio es que esta última interpretación sería temeraria no teniendo como base los dos indicios reseñados antes en torno a la supervivencia del edificio de Alfonso III en el siglo XII. Cuestión ésta, la del mantenimiento del templo alfonsino, en absoluto extraña en el contexto arquitectónico medieval: ejemplos como el de las naves carolingias de las abadías de Vézelay (Yonne ) o de Saint-Denis (Seine Saint Denis), sustituidas en torno a 1120 y 1230 respectivamente, o de la vieja catedral de Notre-Dame de la Basse Oeuvre en Beauvais (Oise), nunca acabada de suplantar por la imponente y malograda estructura gótica, ponen de relieve la amplia persistencia en el tiempo de edificios prerrománicos en instituciones de importancia. Pienso que en Sahagún estaríamos ante un mantenimiento pretendido por el monarca y sólo años después de su muerte revocado ${ }^{39}$.

En esta reconstrucción de la iglesia de Sahagún en tiempos de Alfonso VI se hace ineludible acometer un dato que viene manejándose desde hace décadas: ¿a qué estructura afectó entonces la documentada dedicación del año 1099? En la Primera Crónica Anónima de Sahagún se refiere a que en ese año "llamados muchos obispos, e abbades, e muchos caballeros, e nobles de Espanna, e eso mesmo seyendo presente el sobredicho honrrado varón don Bernardo, arçobispo de To-

\footnotetext{
36 "E luego hizo edificar la iglesia como fasta agora paresce": Crónicas anónimas de Sahagún (A. Ubieto Arteta, ed.), Zaragoza, 1987, p. 11.

37 Quo postea beatorum martirum Facundi et Primitivi basilica ingens et obtima iussu et auxilio Karoli fabricatur, in qua et eorumdem martirum corpora requiescunt: Liber Sancti Jacobi. Codex Calixtinus (K. Hebers y M. Santos Noia, eds.), Santiago de Compostela, 1998, p. 204.

38 J.A. Fernández Flores, Colección diplomática del monasterio de Sahagún (857-1230). V-1200-1300, León, 1994, doc. 1584, pp. 25-28.

39 Expulsados los monjes del monasterio, el estado de la iglesia de Sahagún durante el periodo 11091117 no debió ser óptimo ("la iglesia de San fagum estaba çerrada e non abria nin se çelebrava en la villa el divinal oficio", Crónicas anónimas de Sahagún (A. Ubieto Arteta, ed.), p. 98).
} 
ledo, la iglesia de los preçiosos mártires Facundo y Primitivo con gran alegría e solenidad fiço consagrar" ${ }^{\prime \prime}$. Desde hace tiempo este acto litúrgico se viene asociando a la cabecera románica de tres ábsides de la que aún quedan restos visibles, entre ellos dos capiteles de calidad limitada ${ }^{41}$. Sin embargo el ya mentado hecho de que en la Primera crónica anónima no se explicite en ninguna parte la construcción de un templo ex novo - no hay que olvidar que las obras de la iglesia románica se dilataron hasta el siglo XIII- y que para esta ceremonia religiosa fueran utilizados los términos de consagración y dedicación cuya asociación implica la terminación de un edificio, hace que personalmente no apueste por aquella hipótesis ${ }^{42}$. Más bien creo que la liturgia de 1099 se aplicó al edificio prerrománico una vez que le fue añadida una amplia estructura occidental. $\mathrm{O}$ dicho de otro modo: pienso que Alfonso VI mantuvo la iglesia prerrománica financiada por su homólogo asturiano hacia 900 añadiéndole un bloque a los pies con unas singulares connotaciones litúrgico-escatológicas.

El bloque oeste de Sahagún fue encontrado en una excavación arqueológica realizada en 1932 por el arquitecto Alejandro Ferrant Vázquez (1897-1976) con la asistencia científica de Manuel Gómez Moreno (1870-1970), principal promotor de esta campaña encaminada de modo prioritario a hallar los restos de la iglesia del siglo $\mathrm{X}^{43}$. Una vez desechada su filiación prerrománica y atestiguada de manera

40 Ibid., p. 17.

41 Esta idea se fundamentaba en el epitafio del abad Diego (1088-1110): Ossa cubant petra; transivit spiritus ethra. Vir venerabilis Dux et Monachorum Pater Abbas Didacus primus. Inter cetera pietatis opera ecclesiae fundamentum primus posuit. Crucem mayorem argenteam fabricavit; monasterium Sancti Petri de Domnabus construxit et moniales ibídem instituit Era MCXLVII pro cuius anima quilibet ejus epitaphium relegens intercedat. Romualdo Escalona, a quien debemos la transcripción, indica que se encontraba en el claustro, cerca de la puerta de entrada al templo. Asimismo fue quien apuntó su cronología bajomedieval: el numeral que sigue al nombre implicaría que en el momento de ser redactado ya habría habido un segundo abad Diego que gobernó el monasterio entre 1329 y 1357 (R. Escalona, Historia del Real Monasterio de Sahagún, sacada de la que dexó escrita el padre Maestro Fr. Joseph Perez, catedrático de lenguas y de matemática de la Universidad de Salamanca: corregida y aumentada con varias observaciones históricas y cronológicas y con muchas memorias muy conducentes á la historia general de España, Madrid, 1782, p. 94). La primera asociación de los tres ábsides románicos con el abadiato de Diego remonta a fines del siglo XIX: J. M. Quadrado, Recuerdos y bellezas de España. Asturias y León, Barcelona, 1885, p. 393.

42 Aunque se ha de tener presente que la crónica es una traducción al castellano moderno de la original latina perdida, poco más delante de referirse a la consagración el monje utiliza el término 'dedicación' que, como se sabe, es un acto litúrgico de mayor calado ya que si in stricto sensu la 'consagración' afecta solo a los altares, la 'dedicación', con su rito de purificación de muros y puertas de acceso, exige un edificio completo (Crónicas anónimas de Sahagún (A. Ubieto Arteta, ed.), p. 17).

43 Varios testimonios de cronistas de los siglos XVII y XVIII asociaban con el templo de Alfonso III la parte más occidental de la iglesia de Sahagún (M. Gómez Moreno, Iglesias mozárabes, pp. 202-206, esp. 204).

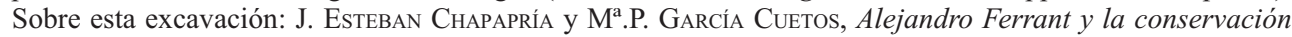
monumental en España (1929-1939), Valladolid, 2007, vol. I, pp. 202-203. Los testimonios modernos sobre el aspecto son varios: “(...) parecida a las antiquísimas de la ciudad de Oviedo (...)” (A. YEPEs, Crónica general de la orden de San Benito, Madrid, 1959 (Irache, 1609-1610), vol. I, pp. 265-266). Lo mismo pensaban los archiveros de Sahagún José Pérez de Rojas y Romualdo Escalona (R. EscALonA, Historiadle Real Monasterio de Sahagún, pp. 232-233) y posteriormente, asumiendo el criterio de los anteriores, Eugenio Llaguno y Juan Agustín Cean (E. Llaguno y Amirola y J.A. Ceán Bermúdez, Noticias de los arquitectos de España desde su 
inequívoca sus líneas románicas, con su habitual perspicacia, Gómez Moreno ya consideró que la dedicación de 1099 debió afectar a esta estructura de netos rasgos románicos si bien no comprendió correctamente su verdadera naturaleza ${ }^{44}$. Como fue puesto de relieve hace algunos años, ese amplio espacio fue erigido para dar cabida a los restos del monarca y de sus esposas y para desarrollar en él una liturgia conmemorativa de la muerte y la resurrección de Cristo ${ }^{45}$. Es decir, un bloque de semejante función a los analizados en los edificios cluniacenses anteriores aunque con una morfología diferente (fig. 14).
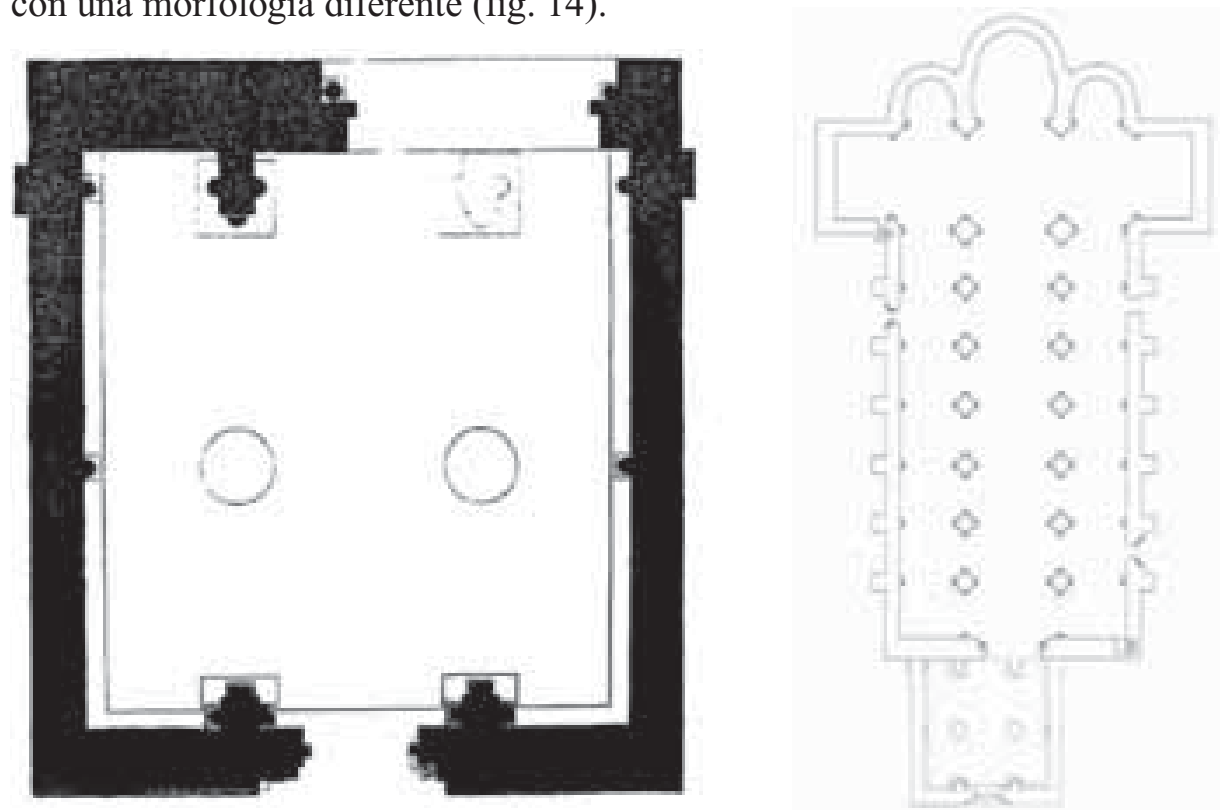

Fig. 14. Santos Facundo y Primitivo de Sahagún. Planta bloque occidental (A. Ferrant) y ensayo de planta de la iglesia románica con el bloque occidental (J. L. Senra).

Se trataba de un espacioso cuadrilátero de 13,5 x 14 metros, de excelente estereotomía, definido con pilares compuestos en sus muros longitudinales, dos centrales exentos y columnas adosadas en los muros transversales, conformando una espaciosa estructura de tres naves muy próxima al panteón de San Isidoro pero superior en tamaño $(9,5 \times 9)$. La potencia de sus muros $(1,30 \mathrm{~m})$ permite sostener

restauración, Madrid, 1829, vol. I, p. 7). El hecho de que en el interior de la estructura se encontraran (desconocemos desde cuándo) los sepulcros de los dos primeros abades del monasterio Alfonso y Recesvinto reforzaba la convicción de asociarla a la iglesia de Alfonso III (A. YePES, Crónica general..., I, p. 266).

44 "No era ella [la estructura dedicada en 1099] el inmenso edificio cuyas ruinas quedan a la vista, sino otro situado a sus pies, que luego se llamó capilla de S. Mancio": M. Gómez Moreno, El arte románico español. Esquema de un libro, Madrid, 1934, pp. 157-158.

45 J. L. SenRA, “Aproximación a los espacios litúrgico - funerarios en Castilla y León: pórticos y galileas” pp. 122-144, esp. 128-130. 
la hipótesis de que contaba con un nivel superior cuyo acceso quizá lo posibilitaran escaleras insertadas en el espesor del muro del hastial $(1,80 \mathrm{~m})^{46}$. De este bloque tan solo podemos analizar de manera directa algunas de sus basas. Creo que es posible afirmar que al menos cinco de ellas se encuentran en el Museo de León desde que fueran extraídas en 1932 $2^{47}$ : el análisis comparativo de estos últimos ejemplares con las fotografías tomadas durante la excavación deja poco margen para la duda ${ }^{48}$ (figs. 15-16). Y si bien la basa es un elemento estructural algo limitado a la hora de proceder a analíticas crono-estilísticas, la decoración presente en los ángulos de todas ellas muestra una neta emancipación respecto al toro inferior, es decir, el ornamento no es resultado de un tratamiento plástico integrado respecto a la basa, rasgo compatible con el entorno de $1100^{49}$.

Aspecto de singular importancia es el de las dos portadas que presentaba: una de comunicación con la iglesia y otra de acceso desde el exterior. A partir de las fotografías tomadas en 1932 ambas parecen coetáneas a la propia estructura ${ }^{50}$. Contando con esas imágenes y con las medidas tomadas durante la excavación, puede establecerse que la portada occidental presentaba una articulación muy próxima y unas dimensiones casi clónicas a la del Cordero de San Isidoro de León por lo que no puede descartarse que incluyera un tímpano, soporte que iniciaba su andadura en la escultura monumental en este tramo cronológico (fig. 14) s. $^{51}$.

Pero con el testimonio de las imágenes reseñadas se puede ir más lejos en cuanto a

46 Tal y como se trasluce en una carta dirigida a Manuel Gómez Moreno, la anchura de estos muros llamó la atención de Alejandro Ferrant (J. Esteban Chapapría y Ma.P. García Cuetos, Alejandro Ferrant y la conservación monumental en España, I, p. 213) si bien, en relación con las mentadas escaleras inter-murales, desconocemos si el arquitecto excavó el perímetro completo del edificio. Una estructura occidental de dos niveles como la del priorato cluniacense suizo de Romainmôtier presenta un espesor de muro occidental de $1,80 \mathrm{~m}$. en el que se insertaron unas escaleras de tramo recto. (H.R. SENNHAUSER, Romainmôtier und Payerne. Studien zur Cluniazenserarchitektur des 11. Jahrhunderts in der Westschweitz, Basel, 1970, pp. 28-30, figs. 70-74). Por su parte, los muros laterales, con un espesor de 1,30 m. semejante al de Sahagún, sustentan un segundo nivel.

47 A propósito de la estructura occidental, considerándola inicialmente parte del templo de Alfonso III, en una de las cartas de Gómez Moreno a Ferrant se señala: "Quizá debamos arrancar algunas basas y llevarlas al museo de León donde están sus capiteles" (J. Esteban Chapapría y Mª.P. García Cuetos, Alejandro Ferrant y la conservación monumental en España, I, p. 215). Quiero mostrar mi agradecimiento a Luis Grau y Manuel García (Museo de León) por su amabilidad al procurarme la imagen aquí publicada (fig. 15).

48 Hasta ahora habían sido asociadas a la iglesia de los siglos XII-XIII (Mª.V. Herráez Ortega (coord.), Esplendor y decadencia de un monasterio medieval. El patrimonio de san Benito de Sahagún, León, 2000, pp. 115 y 130 [figs. 94-98]).

49 Un trabajo clásico sobre este asunto: F. Deshoulières, "Essai sur les bases romanes”, Bulletin Monumental, LXXV (1911), pp. 77-101, esp. 98-100.

50 Se ha especulado con que la portada occidental fue añadida a una estructura que inicialmente habría tenido un pequeño vano y además se encontraría cerrada a la iglesia en su muro oriental (M ${ }^{\mathrm{a}}$.V. HERRÁEZ Ortega (coord.), Esplendor y decadencia de un monasterio medieval. El patrimonio de san Benito de Sahagún, pp. 62-63).

${ }_{51}$ Al igual que tantas iglesias, en el tema que nos ocupa, San Zoilo y Frómista, el acceso principal de la iglesia de Sahagún se encontraría en el flanco norte, el opuesto a la clausura. 


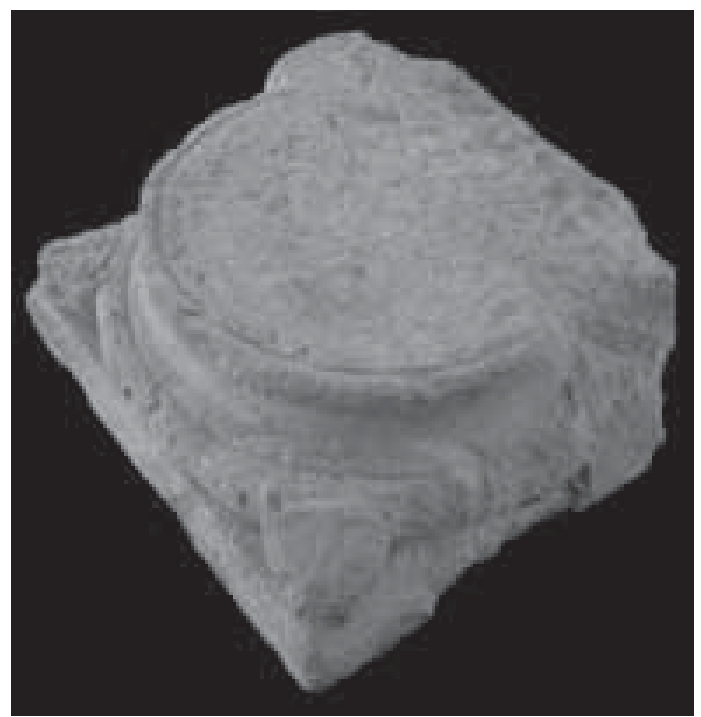

Fig. 15. Santos Facundo y Primitivo de Sahagún. Basa descontextualizada (Museo de León).

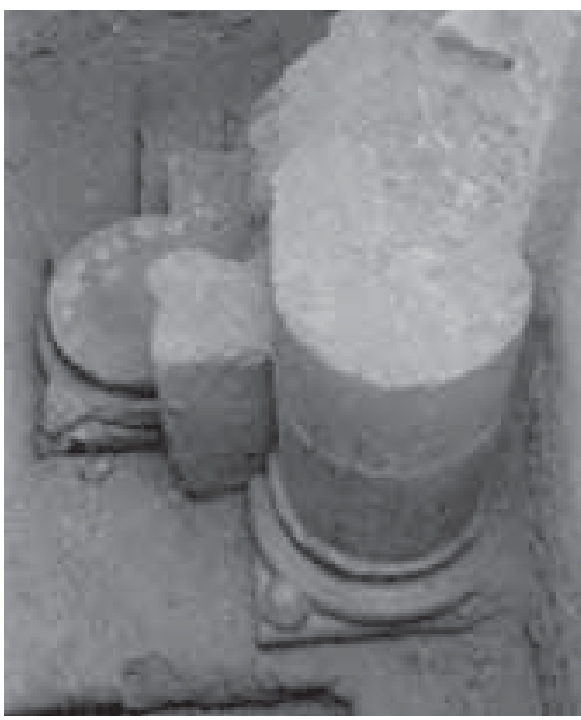

Fig. 16. Santos Facundo y Primitivo de Sahagún. Excavación 1932 (Foto: Col.legi d'Arquitectes de Catalunya, Lleida).

la interpretación del acceso a la iglesia. Cuando se observa el contacto de la estructura occidental con el hastial oeste de la iglesia románica es posible diferenciar los muros de cada una de las dos arquitecturas, cuestión que la planta levantada tras la excavación omite (fig. 14) ${ }^{52}$. El arquitecto se abstrajo de plasmar este encuentro de muros diferentes dando a todo ello un tratamiento uniforme. Son dos las fotografías que permiten constatar que los muros longitudinales del bloque, a la altura del hastial del templo se abrían transversalmente en dirección norte y sur respectivamente. Concretamente es el meridional el que aparece y puede verificarse en la fotografía indicada (figs. 17-18). Esta apertura se realizaba sobre la iglesia precedente a la románica; es decir, según mi opinión, se abría a la iglesia del siglo X (figs. 19-20-21). En relación con ello, hay otra importante cuestión: la morfología de los pilares orientales del bloque occidental. Aparecen limitados por el muro de la iglesia románica del XII-XIII y, comparados con los del muro opuesto, el occidental, se destacan hacia el interior del espacio del propio bloque. A mi modo de ver, al igual que puede verse con frecuencia en otras yuxtaposiciones de estructuras cronológicamente divergentes entre sí, enlazaban con los pilares de separación de las naves del edificio del siglo X. Si como pienso, esta estructura se abría a las naves del templo de Alfonso III, lo hacía mediante un triple acceso (A-B-A), tipología procedente del arco de triunfo romano, absorbido por la arquitectura palatina y sintetizada a través del concepto genérico de

52 Quiero agradecer al arqueólogo Julio Vidal Encinas su llamada de atención en torno a esta duplicidad de estructuras visible en la fotografías de la colección Ferrant publicadas en J. Esteban Chapapría y M M $^{\text {P }}$ García Cuetos (op. cit., n. 43). 


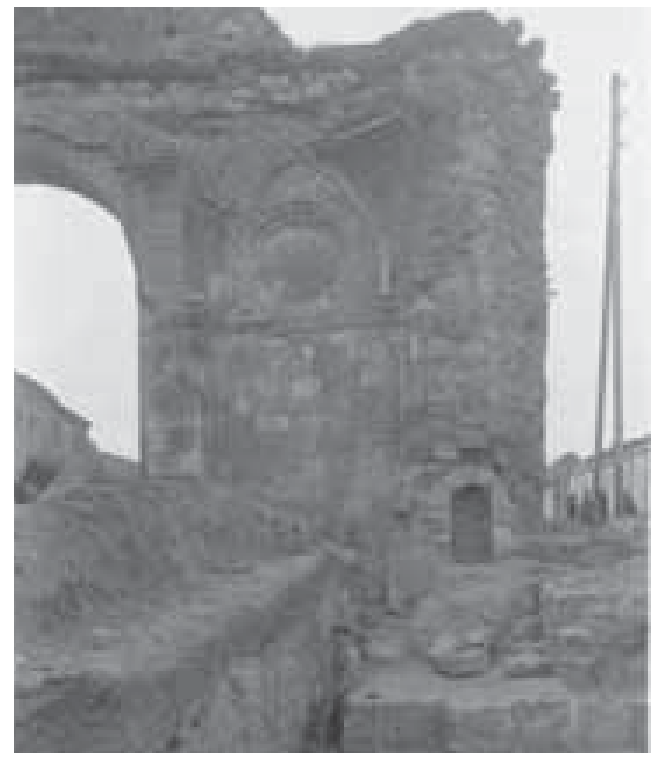

Fig. 17. Santos Facundo y Primitivo de Sahagún. Excavación 1932 (Foto: Col.legi d'Arquitectes de Catalunya, Lleida). ciudad hasta su concreción en el templo: la vía triunfal de acceso a la Civitas Dei a través de la victoria de Cristo sobre el pecado y la muerte ${ }^{53}$ (fig. 22). Tal solución, perfectamente adecuada además para el desarrollo de la liturgia procesional, encontraba un claro parentesco con el territorio en el que, durante el periodo románico inicial, más ampliamente se desarrolló este estereotipo de triple umbral en combinación con los espacios escatológicos occidentales: Borgoña.

Un ejemplo muy explícito se encuentra en la abadía de Saint-Germain d'Auxerre (Yonne) cuya estructura oeste, de raíz carolingia, experimentó una dinámica evolución entre los siglos X y XII planteando desde su inicio el triple vano (fig. 23) ${ }^{54}$. Esta misma solución aparece

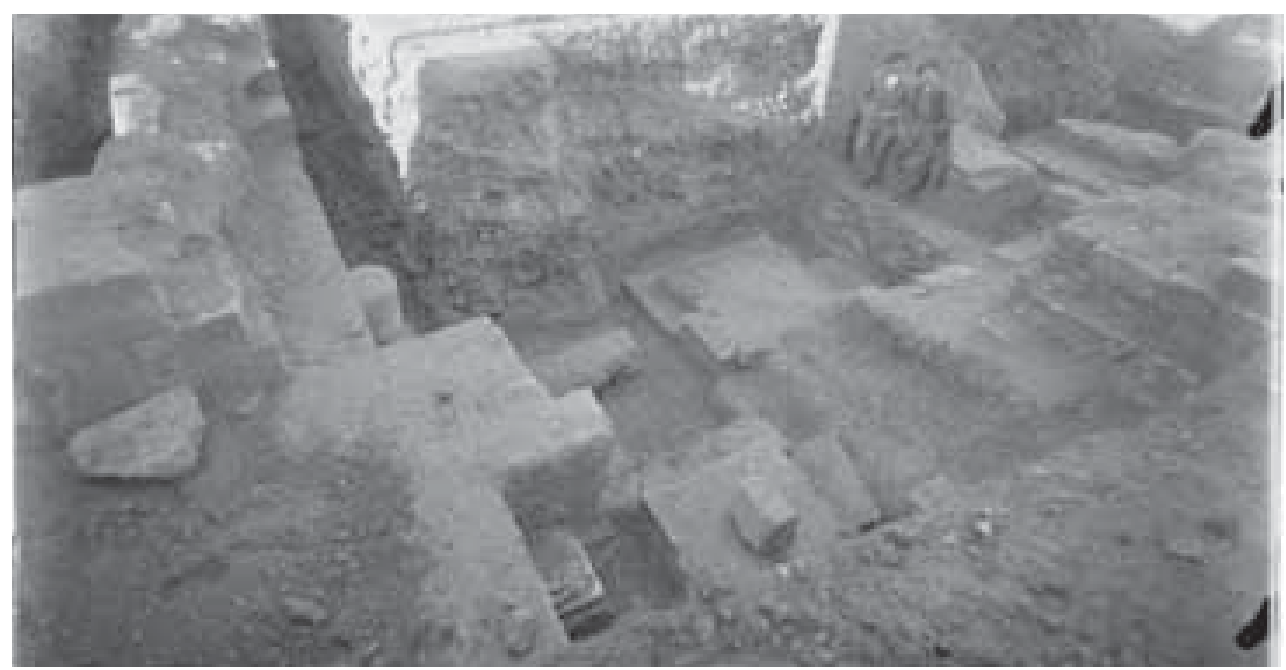

Fig. 18. Santos Facundo y Primitivo de Sahagún. Excavación 1932 (Foto: Col.legi d'Arquitectes de Catalunya, Lleida).

53 Para la significación simbólica de la triple arcada y del portal torreado: G. BAndmann, Early Medieval Architecture as Bearer of Meaning (H.J. Böker, ed.), Nueva York, 2005 (Berlín, 1951), pp. 113-118; B. SмIт,, Architectural Symbolism of Imperial Rome and the Middle Ages, Nueva York, 1978, pp. 75-106. Sobre la asimilación de este esquema en el mundo hispánico si bien limitado a la distribución interior del templo, separación cuerpo de naves-coro monástico ver: Isidro G. BANGO ToRviso, "Alfonso II y Santullano", en: Arte prerrománico y románico en Asturias, Gijón, 1988, pp. 207-237, esp. 209-219.

54 C. SAPIN, "D'Auxerre à Cluny, le dossier archéologique des premières avant-nefs et galilées", en Avant-nefs et espaces d'accueil dans l'église entre le IV et le XII siècle (C. Sapin, dir.), París, 2002, pp. 398-413, esp. 400-402. 


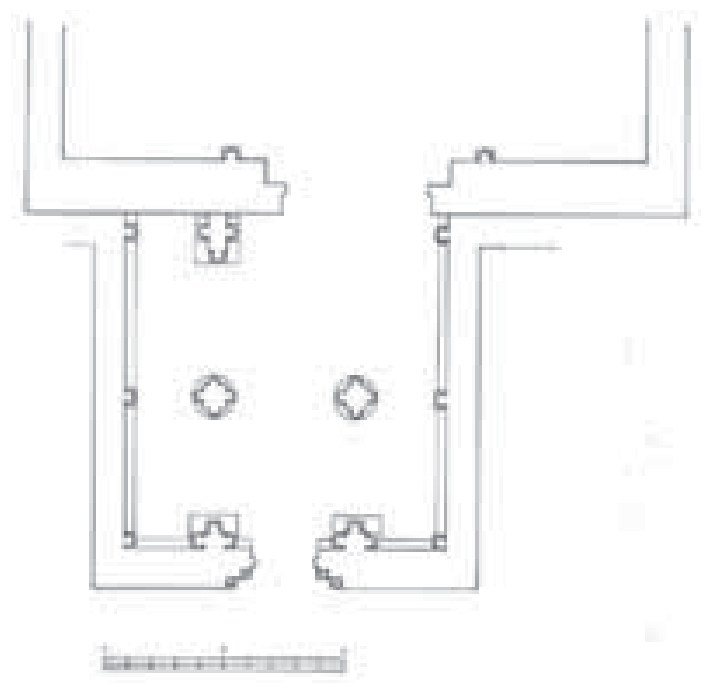

Fig. 19. Santos Facundo y Primitivo de Sahagún. Planta bloque occidental en su engarce con la iglesia de los siglos XII-XIII (J. L. Senra).

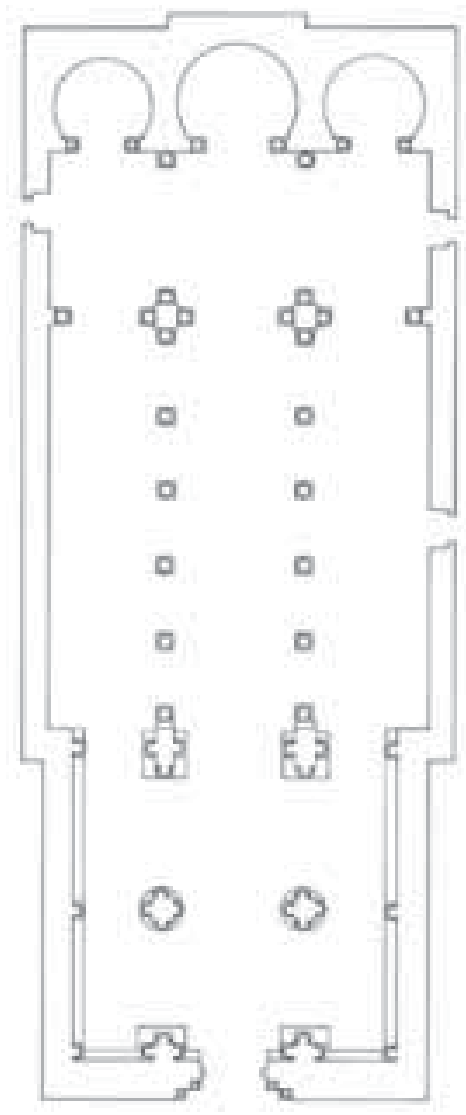

Fig. 20. Santos Facundo y Primitivo de Sahagún. Planta hipotética de la iglesia del siglo X y del bloque occidental (J. L. Senra).
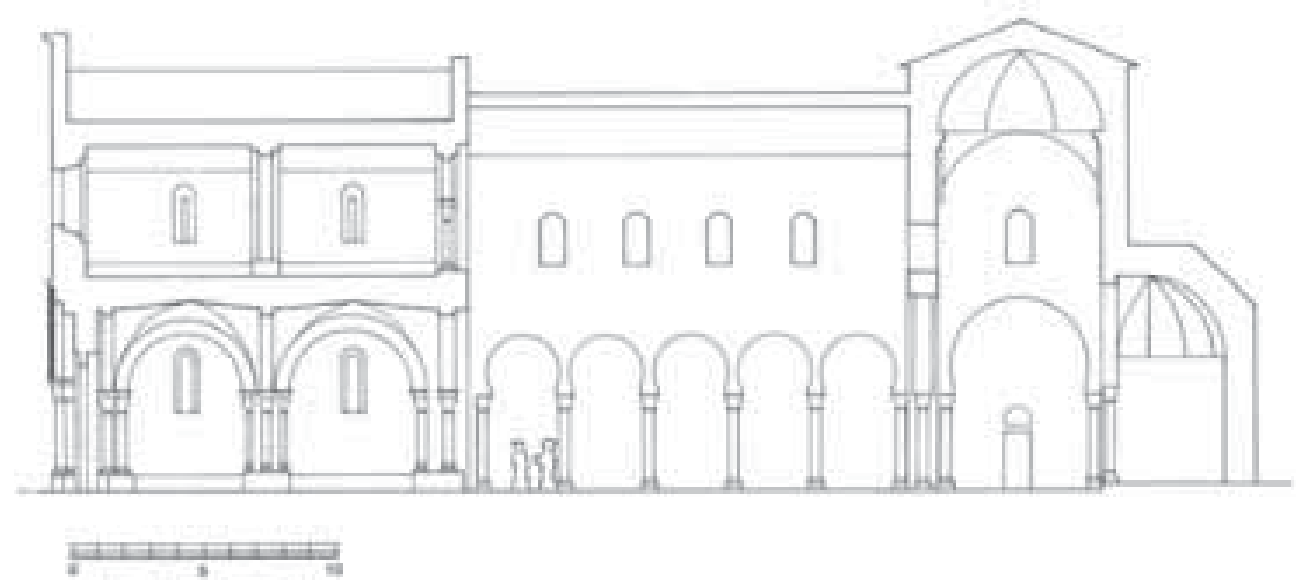

Fig. 21. Santos Facundo y Primitivo de Sahagún. Sección longitudinal hipotética de la iglesia del siglo X y del bloque occidental (J. L. Senra). 

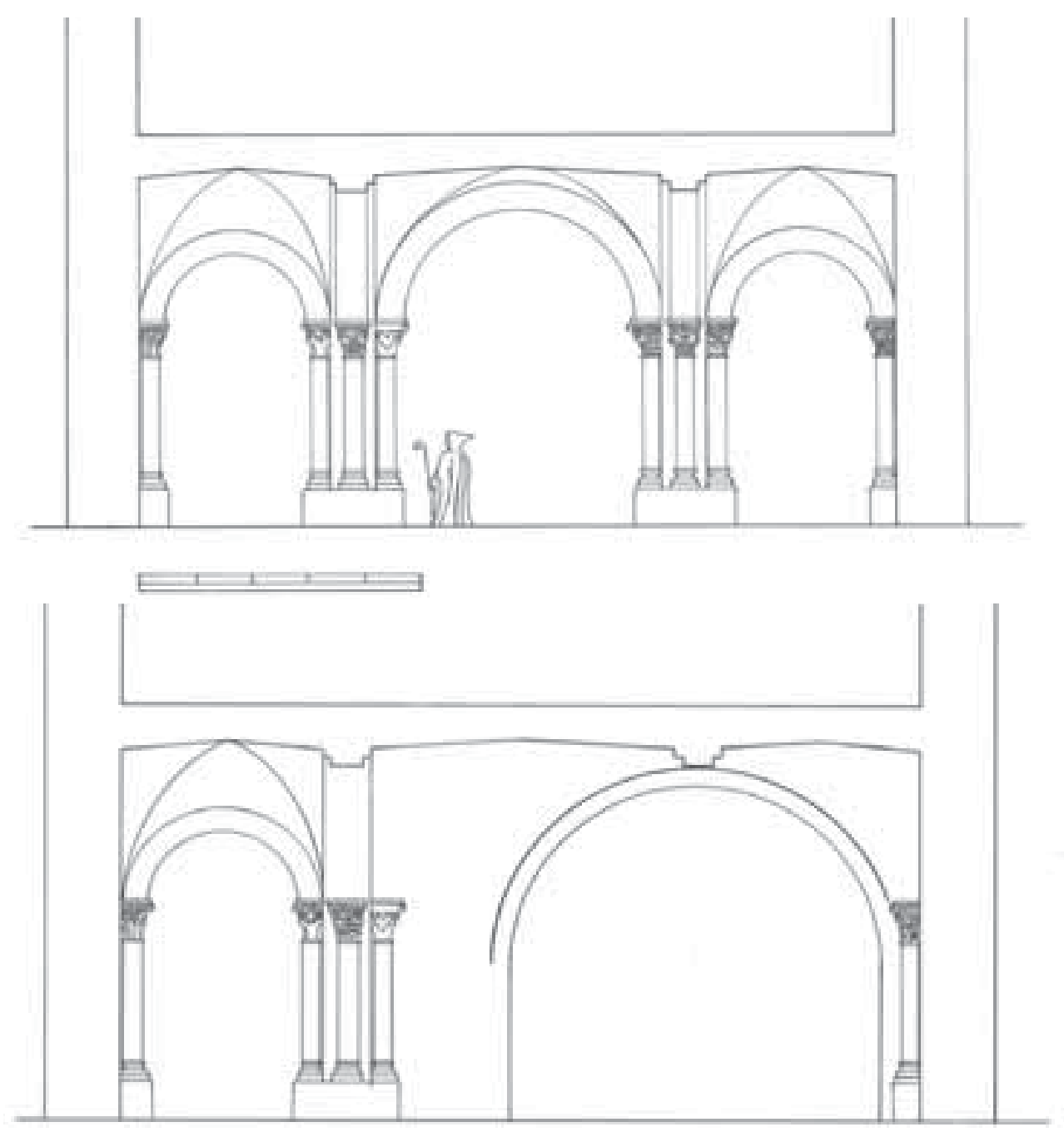

Fig. 22. Santos Facundo y Primitivo de Sahagún. Reconstrucción hipotética del acceso a la iglesia desde el bloque occidental (a) y estado tras la adaptación a la iglesia de los siglos XII-XIII (b) (J. L. Senra).

adoptada hacia 1035 en la galilea de la abadía de Saint-Philibert de Tournus (Saôneet-Loire) [figs. 24-25], de modo afortunado conservada prácticamente en su integridad, y un siglo más tarde en la de la Sainte-Madeleine de Vézelay (Yonne) [fig. 

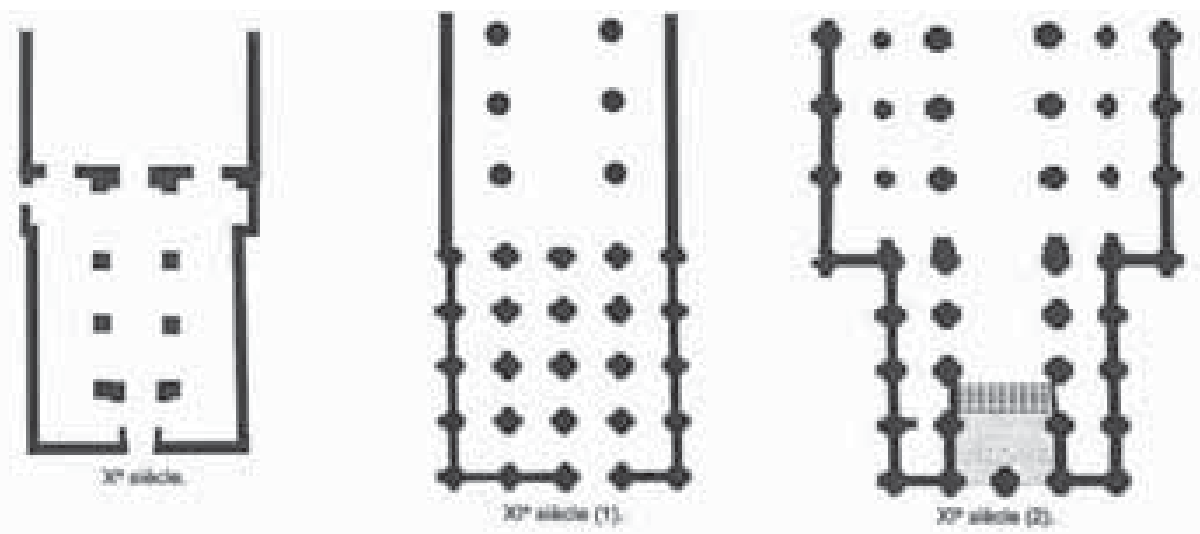

Fig. 23. Saint-Germain d'Auxerre. Evolución del bloque occidental ss. X-XI (C. Sapin).

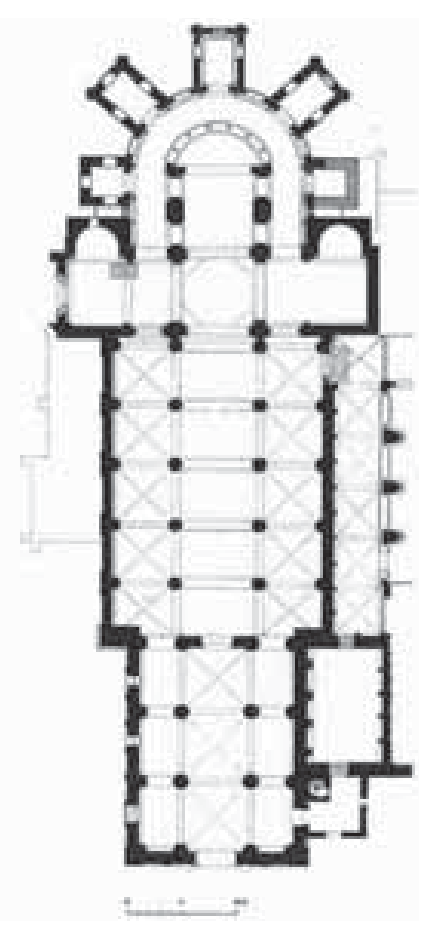

Fig. 24. Saint-Philibert de Tournus. Planta de la iglesia ca. 1040 (J. Henriet). $26]^{55}$. A partir de su codificación carolingia desde el substrato romano y posteriormente de su éxito en la arquitectura normanda, es sobradamente conocido el auge de este esquema tripartito en el exterior de las grandes fachadas de los templos desde mediado el XII con ejemplos tan rotundos como el bloque occidental de Saint-Denis (ca. 1135) o la fachada oeste de la catedral de Chartres (ca. 1145) ${ }^{56}$. La importancia de un acceso porticado triple no es cuestión banal en un territorio, la Península Ibérica, en el que con los datos que tenemos no aparece de modo plenamente desarrollado hasta la remodelación de la fachada oeste de la catedral de Santiago de Compostela con el umbral de triple acceso que hoy conocemos como Pórtico de la Gloria (1188) [fig. 27].

En Sahagún debió trazarse un triple acceso de desarrollo intermedio respecto a los dos modelos borgoñones mencionados, Tournus y Vézelay: en principio la limitada anchura de los pilares apuntaría a la no presencia de tímpanos siendo los capiteles los receptores de decoración (fig. 22). Y a la hora de pre-

55 Para la galilea de Tournus: J. Henriet, Saint-Philibert de Tournus. L'abbatale du XIe siècle, París, 1992, pp. 89-124. El esquema tripartito estaba presente en la tercera iglesia de Cluny (ca. 1120-1130) si bien de modo menos equilibrado en la relación entre puertas laterales y puerta central (K.J. ConAnt, Cluny. Les églises et la maison du chef d'ordre, Mâcon, 1968, pp. 100-102, pl. XLII, fig. 77).

56 Un estudio ya clásico sobre la expansión normanda de esta tipología de fachadas: J.P. McAleER, "Romanesque England and the Development of the Façade Harmonique", Gesta, XXIII (1984), pp. 87-105. 


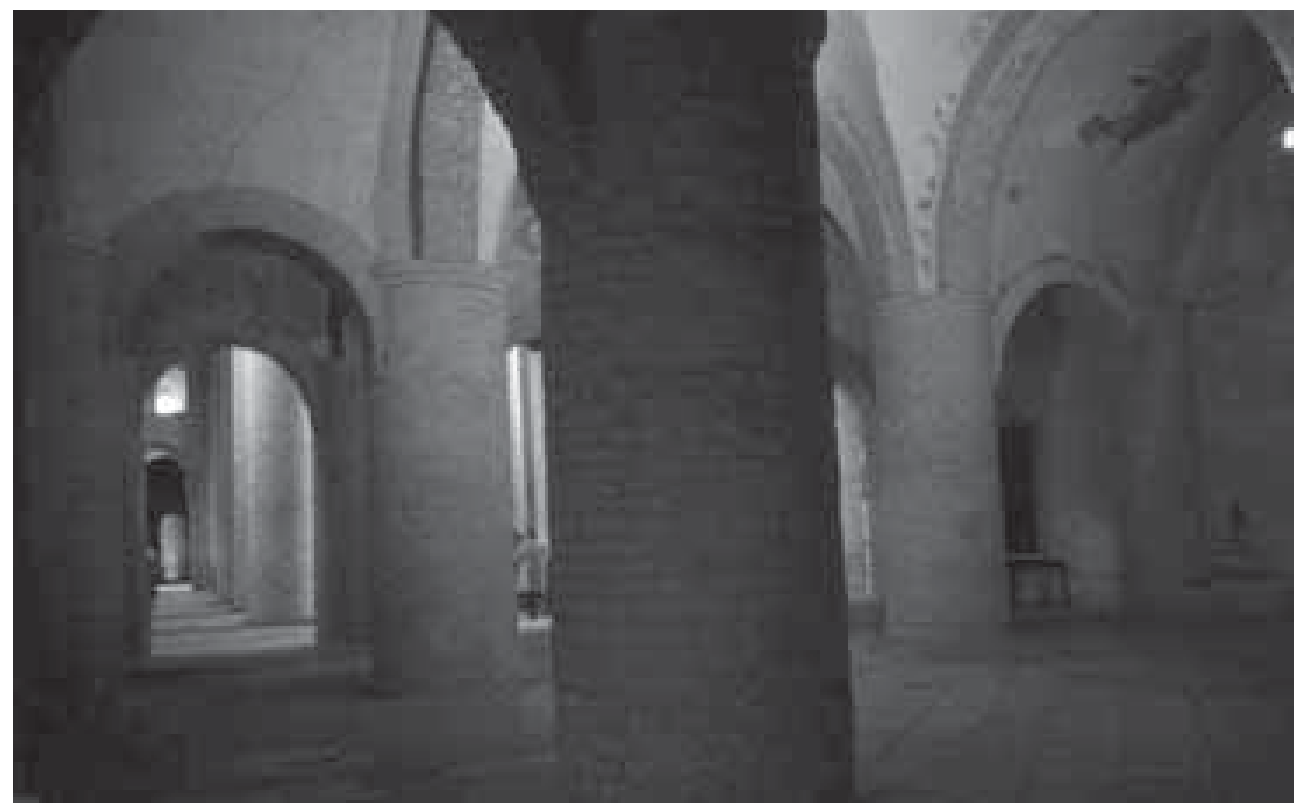

Fig. 25. Saint-Philibert de Tournus. Acceso a la iglesia desde la galilea (Foto: J. L. Senra).

cisar estilos ornamentales pleno-románicos presentes en Sahagún y que pudieran haber sido asimilados por la estructura occidental, los únicos referentes con que contamos son antagónicos: por un lado los relieves de Cristo (Colección particular) y la Virgen (Museo Arqueológico Nacional) en Majestad ${ }^{57}$; por otro, la ya mentada lauda de Alfonso Pérez (ob. 1093) y finalmente el capitel del ángel y la esfinge, de estilística isidoriana, estas dos piezas también en el Museo Arqueológico Nacional ${ }^{58}$.

Pero regresando a la cuestión arquitectónica, entre la historia de Tournus y la de Sahagún contamos con un importante nexo: la segunda esposa de Alfonso, la reina Constanza (1079-1093) ${ }^{59}$. Sobrina del abad Hugo de Cluny (1049-1109), Constanza nació hacia 1050 probablemente en Dijon, matrimoniando con el conde Hugo II de Chalon (1065-1078) ${ }^{60}$. La Civitas Cabillonensis, núcleo de poder de Hugo, se

57 Sobre estas dos piezas descontextualizadas: J.L. SENRA, "Una olvidada Maiestas Domini procedente del monasterio benedictino de Sahagún”, en El tímpano románico: imágenes, estructuras y audiencia (R. Sánchez y J.L. Senra, eds.), Santiago de Compostela, 2003, pp. 209-229.

${ }_{58}$ Como se sabe, tanto los dos relieves como la lauda sepulcral son de mármol. La presencia de este material de ornamentación en el bloque occidental aparece consignado tanto por los restos que aparecieron (fustes y basas) como por testimonios antiguos como el de Yepes al indicar que en él podían verse "diferentes columnas y con mármoles y jaspes” (A. YePEs, Crónica general de la orden de San Benito, I, pp. 265-266).

59 Constanza era hija del duque de Borgoña Roberto I el Viejo (1032-1076) y de Helia de Semur (ob. 1109), hermana a su vez del abad Hugo de Cluny (N. Hunt, Cluny Under Saint Hugh, 1049-1109, Londres, 1967, pp. 26-27).

${ }^{60}$ Según las estimaciones derivadas del estudio antropológico de sus restos, Encina Prada Marcos y Julio Vidal Encinas, consideran que la reina Constanza murió en 1093 contando entre cuarenta y cincuenta años ("El 


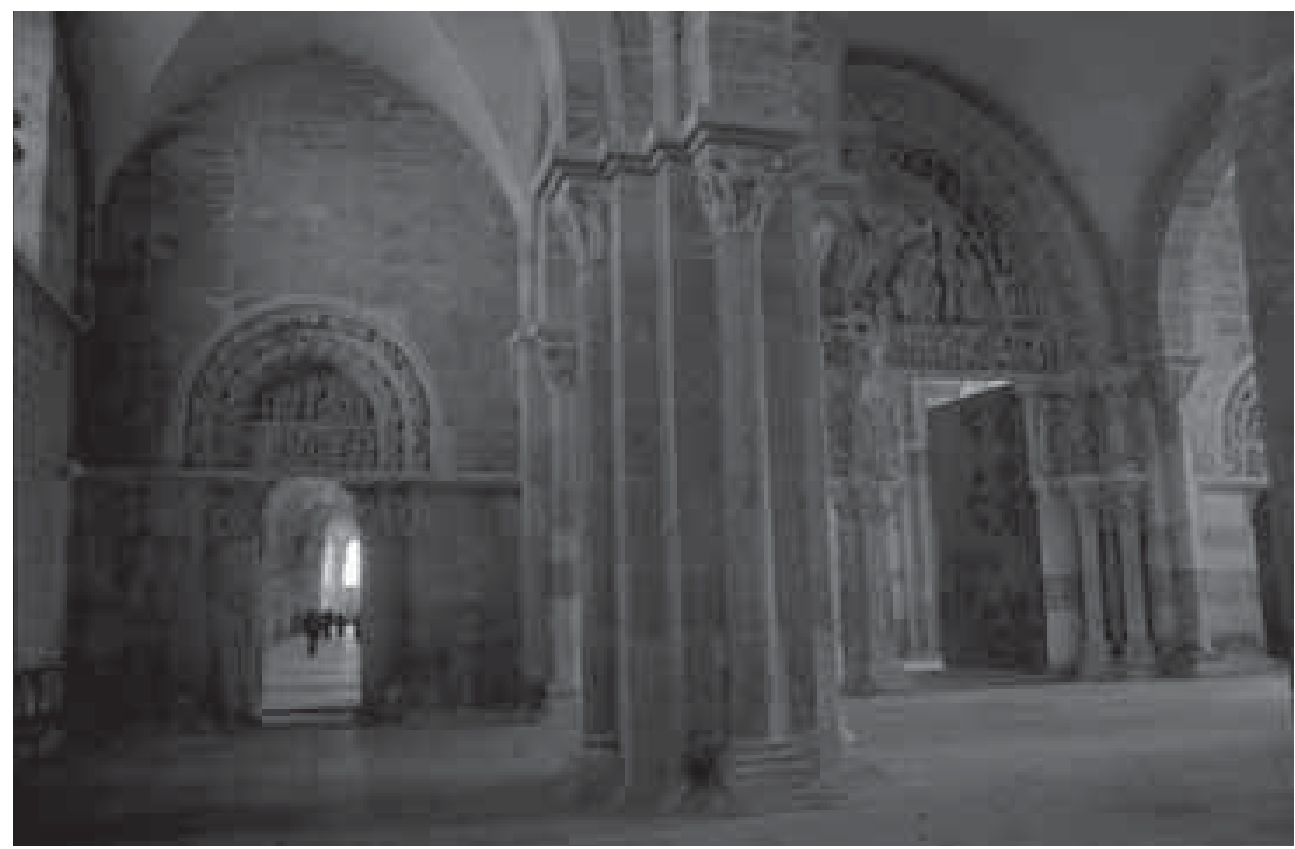

Fig. 26. Sainte-Madeleine de Vézelay. Acceso a la iglesia desde la galilea (Foto: J. L. Senra).

encuentra a solo 27 kilómetros al norte de Saint-Philibert de Tournus, sin duda la institución religiosa con más prestigio del dominio condal ${ }^{61}$. De hecho, la Crónica del monje Falcón, fuente documental básica para el conocimiento del monasterio en ese periodo, es categórica a la hora de subrayar la devoción de Constanza por las reliquias de san Filiberto e incluso reseñar la gestión llevada a cabo por su abad Pedro I (1066-1107) en la concreción de sus segundos esponsales con Alfonso ${ }^{62}$.

monasterio y panteón de Alfonso VI en Sahagún: aspectos históricos y arqueo-antropológicos", en Congreso internacional Alfonso VI y su legado. Sahagún, 29-31 octubre 2009 [en prensa]). Según ello habría nacido entre 1045-1050, llegaría a León con aproximadamente treinta (1079) y moriría con unos cuarenta y cinco (1093).

${ }^{61}$ El monasterio de Tournus, fuertemente influenciado por los usos cluniacenses, formó una congregación monástica propia que alcanzó su máximo desarrollo entre los siglos XI y XII (M. PACAUT, "Une communauté monastique originale. La congrégation de Tournus (IX ${ }^{\mathrm{e}}-\mathrm{XII}{ }^{\mathrm{e}}$ siècles)", en Saint-Philibert de Tournus. Histoire. Archéologie. Art (Actes du Colloque du Centre International d'Études Romanes, Tournus, 15-19 Juin 1994), Mâcon, 1995, pp. 104-119).

${ }^{62}$ Se trata del Cronicón de Tournus (Cronicon Trenorchiense) escrito por el monje Falco entre 1087 y 1105. Además nos informa de la donación de Constanza a la abadía, antes de marchar a León en 1079, de una iglesia en Givry y de un anillo cuya gema (topazius nominatur) se injertó en las cubiertas unos Evangelios del monasterio (Monuments de l'Histoire des Abbayes de Saint Philibert (A. Giry y R. Poupardin, eds.), París, 1905, pp. 104-106). Ocho años después de haberse trasladado a León (1087), su primo Eudes, duque de Borgoña (1079-1103), se encontró con ella en la ciudad regia encabezando una expedición militar de ayuda tras la derrota de Alfonso en la batalla de Sagrajas (1086). Allí Eudes, ratificó un diploma de Constanza confirmando la antigua donación a la abadía borgoñona (B.F. ReILly, El reino de León y Castilla bajo el rey Alfonso VI, 1065-1109, Toledo, 1989 (Princeton, 1987), pp. 216-217). Por otra parte, el Cronicón de Tournus indica que en el contingente borgoñón se encontraban dos monjes del monasterio (p. 105). 


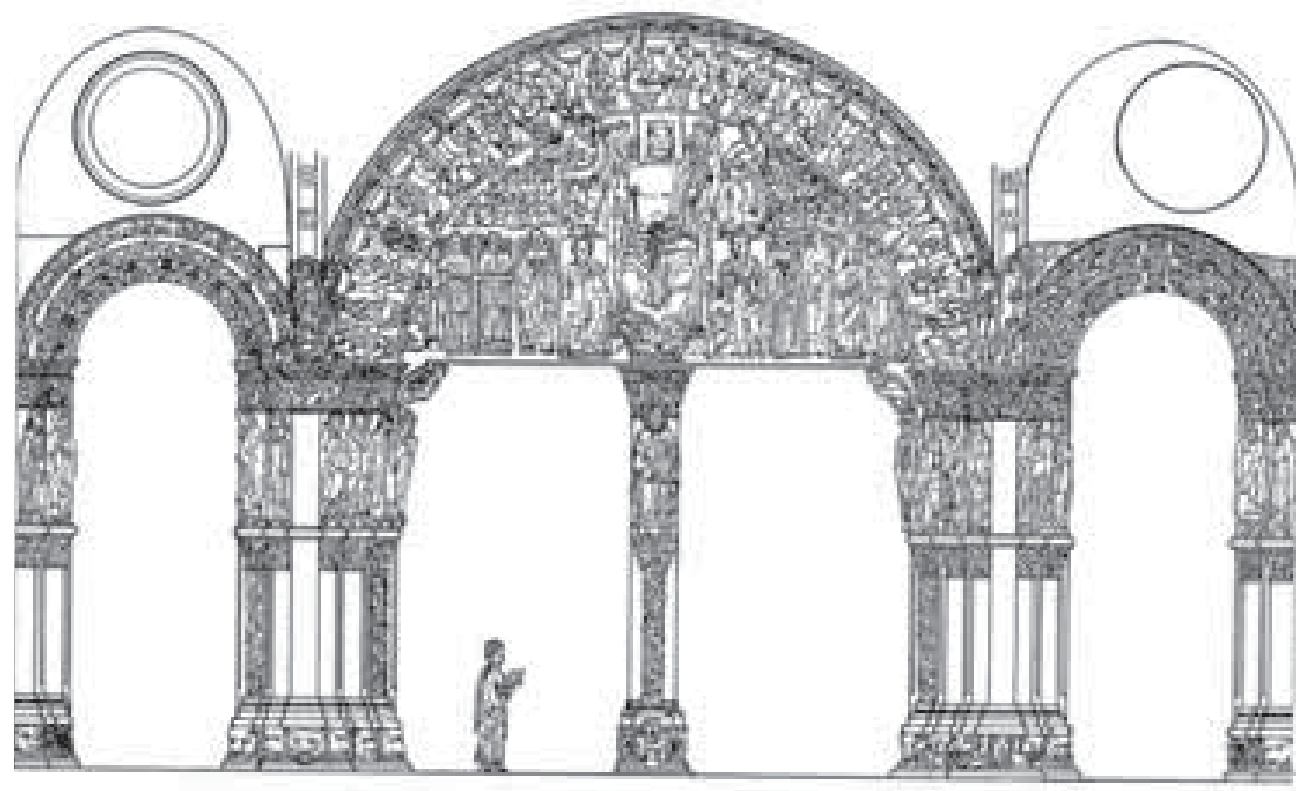

Fig. 27. Catedral de Santiago de Compostela. Pórtico de la Gloria (J. Vilariño).

Ciertamente a partir de su triple acceso al templo, la equidistancia entre el bloque occidental de Sahagún respecto al de Tournus es bastante acusada si bien, más allá de la frecuente presencia de Constanza en el monasterio leonés desde 1080 hasta su fallecimiento en 1093, es decir, hasta seis años antes de la presunta dedicación del bloque, carecemos de información documental que nos permita poder ir más allá ${ }^{3}$. Sí sabemos de la actividad de Constanza en la mejora del conjunto de Sahagún: parece que financió la construcción de un palacio y de unos baños así como de una iglesia dedicada a la Magdalena ${ }^{64}$. Tras su óbito sus restos debieron reposar en el bloque occidental permaneciendo en él durante dos siglos ${ }^{65}$. Y más

${ }^{63}$ La devoción de la reina a la Magdalena, culto profundamente borgoñón, de quien conservaba una reliquia de la que se hace mención en la Primera crónica anónima (Crónicas anónimas de Sahagún, p. 56) hizo que en el palacio se realizara esta capilla bajo su advocación: “(...) el palacio e iglesia de santa María Magdalena e el baño que la reina Constanza susodicha a su costa y propia mesión había edificado" (Crónicas anónimas de Sahagún, p. 23). Ver documento en: M. Herrero de LA FuENTE, Colección diplomática de Sahagún (857-1230). III-1073-1109, doc. 914, pp. 240-242; A. GAMBRA, Alfonso VI. Cancillería, curia e imperio. II Colección diplomática, León, 1998, doc. 128, pp. 328-330. La iglesia de la Magdalena se encontraba dentro del encintado monástico y parece que aún podían contemplarse sus ruinas a comienzos del siglo XVII (A. YePes, Crónica general..., I, p. 365).

${ }^{64}$ Tres de las cinco esposas de Alfonso fueron enterradas en Sahagún: Inés (ob. 1078), Constanza (ob. 1093) y Berta (ob. 1100). A ellas habría que sumar a Zaida, madre de Sancho su único hijo varón fallecido en Uclés. Los restos de su cuarta esposa, Isabel (ob. 1107), se encuentran en San Isidoro de León. Finalmente su última compañera, Beatriz, regresó a su tierra de origen tras la muerte de Alfonso. Sobre las mujeres de Alfonso: A. Gambra, Alfonso VI. Cancillería, curia e imperio. I Estudio, León, 1998, pp. 445-477.

65 La coexistencia de partes arquitectónicas diferenciadas espacial y cronológicamente en un templo era muy frecuente en la Edad Media. Los ejemplos se hacen más claros cuando se trataba de áreas occidentales 
allá de su posible derivación de Tournus, la presencia del triple arco dividiendo el espacio funerario del espacio eclesial no podía sugerir sino una prefiguración a modo de metáfora visual del triunfo final de la vida eterna sobre la muerte al final de los tiempos y el acceso al reino de los cielos.

En cualquier caso, la iglesia de Sahagún en tiempos de Alfonso VI presentaba una morfología bipolar: un edificio prerrománico a cuyo hastial se le habría añadido un bloque de léxico y orientación litúrgica ajena a la tradición hispana ${ }^{66}$. El déficit de sepulturas de ancestros que presentaba el monasterio respecto al tradicional enterramiento familiar de San Isidoro de León ponía de relieve algo consustancial a las inhumaciones de la monarquía de León-Castilla a partir de Alfonso VI: la solidez de las bases del poder ${ }^{67}$. Podría decirse que en Sahagún, desde la autoproclamación hegemónica por parte del monarca como Imperator totius Hispaniae y el refuerzo de prestigio a través de la toma de Toledo (1085), la carga de legitimidad y búsqueda de apariencia sacra que presenta todo mausoleo se elaboró a partir de la custodia de uno de los edificios más notables del periodo astur-leonés y su asociación al nuevo espacio funerario regio ${ }^{68}$. No debe olvidarse que, como ya indiqué, la basílica prerrománica era un edificio edificado con el mecenazgo de Alfonso III de Oviedo, monarca exaltado de modo singular por la diplomática del siglo X como Magni Imperatoris y por la cronística de la primera mitad del XI como hábil guerrero contra el infiel, devoto y prudente en todas sus decisiones ${ }^{69}$.

añadidas a posteriori: uno de los varios ejemplos que pueden traerse es el del sub-priorato cluniacense de Saint-Pierre-et-Saint-Benoit de Perrecy-les-Forges, dependiente de la abadía Saint-Benoît-sur-Loire. Fundado como monasterio a fines del siglo IX, Perrecy presenta una nave de la primera mitad del XI, una cabecera del XIII y un bloque occidental del primer tercio del XII (ca. 1120-1130) (P.P. ZALEwSKI, "Architektur im Umkreis von Cluny: Zur Baugeschichte einer südburgundischen Prioratskirche in Perrecy-les-Forges", en Koldewey Gesellschaft, Bericht über die 42. Tagung für Ausgrabungswissenschaft und Bauforschung 2002, Stuttgart, 2004, pp. 166-176).

${ }_{66}$ La dispersión de enterramientos ya estaba presente en el periodo astur. Sobre este asunto: A. GUIANCE, Los discursos sobre la muerte en la Castilla medieval (siglos VII-XV), Valladolid, 1998, pp. 314-318.

67 Cuando Alfonso VI explicita en un documento de 1080 su voluntad de inhumarse en Sahagún (Ver documento en nota 33), el reconocimiento de la dignidad imperial era reconocida, no ya por él mismo desde 1077, sino por la cancillería pontificia de Gregorio VII al referirse al monarca como super omnes Hispaniae reges (J.M. Minguez, Alfonso VI. Poder, expansión y reorganización interior, Hondarribia, 2000, p. 218).

${ }^{68}$ La crónica del obispo Sampiro (ca. 1030-1040), insertada en la llamada Historia Seminense, se refería al monarca con calificativos que a lo largo de su relato solo utiliza para aludir a los emperadores romanos como prudentissimus, gloriosissimus y serenissimus; por otro lado, adjetivos plenamente afincados en las cancillerías carolingias (Historia Silense, (J. Pérez Urbel y A. González Ruiz-Zorrilla, eds.), Madrid, 1959, pp. 159-162). Sobre este tratamiento privilegiado: R. BARKAI, Cristianos y musulmanes en la España medieval (El enemigo en el espejo), Madrid, 1984, pp. 44-47. Una síntesis sobre la titulación imperial de Alfonso VI: J.M. MingueZ, Alfonso VI. Poder, expansión y organización interior, pp. 211-218. Para la conformación de la idea imperial, más ampliamente: J.A. MaravalL, El concepto de España en la Edad Media, pp. 412-443. Una revisión reciente del tema en: A. Gambra, Alfonso VI. Cancillería, curia e imperio. I Estudio, pp. 671-714.

${ }^{69}$ Sobre el uso de signos e imágenes sacras por parte de la realeza hispana: J. M. Nieto Soria, "Tiempos y lugares de la «realeza sagrada» en la Castilla de los siglos XII al XV", en: A la recherche de légitimités chrétiennes. Représentations de l'espace et du temps dans l'Espagne médiévale (IX'-XIII ${ }^{e}$ siècle) (P. Henriet, ed.), Dijon-Quetigny, 2003, pp. 263-281, esp. 266-275. 
La justificación del presente a través del pasado y la búsqueda de una presencia futura, piedra angular de la legitimidad dinástica, encontraba en Sahagún un nuevo entorno sagrado ${ }^{70}$. Se diría que en él cristalizaba la voluntad de un rey de asociar su memoria a dos realidades: la autóctona sobre la que se sustentaban los cimientos de su poder y la foránea a través de un modelo de piedad, la cluniacense, que garantizaba por encima de cualquiera otra la salvación eterna de su alma ${ }^{71}$. Por lo demás, la memoria funeraria propuesta por Alfonso se asimilaba a la referida tradicional mecánica del poder, fundamentada en ejercer su dominio en el presente y proyectarse sobre la posteridad ${ }^{72}$. Los sucesores de Alfonso no concedieron continuidad al panteón de Sahagún pero, hasta que a fines del siglo XIII (1286) fuera desvirtuado por Sancho IV trasladando el cuerpo real y los de sus esposas al coro de la iglesia, debió mantener un sólido contenido monolítico asociado al mayor logro del monarca: la conquista de Toledo (1085). Con ella obtuvo un importante doble botín más tarde rentabilizado por Alfonso VII y sus sucesores: uno geoestratégico a partir del traslado de la línea fronteriza cristiana desde el Duero al Tajo; otro ideológico al hacerse con el núcleo del antiguo poder visigodo. No puede extrañar que al poco de haber sido inhumado, la estructura occidental se convirtiera en un espacio específico de evocación y memoria de la figura del monarca y de su gesta conquistadora.

\section{Conclusiones}

A partir de la donación de importantes instituciones monásticas, durante el reinado de Alfonso VI se produjo el asentamiento de la orden de Cluny en los reinos de León, Galicia y Castilla. Los conjuntos monumentales recibidos respondían a una arquitectura autóctona quizá con algunos resabios ornamentales foráneos. A partir de los conocimientos que tenemos hasta la fecha se hace difícil considerar su sustitución hasta, como mínimo, la última fase del gobierno del monarca. Con ello y siguiendo los parámetros litúrgicos generados durante la primera mitad del siglo en Cluny, se implantó un tipo de arquitectura que ponía un singular acento en las fachadas occidentales. Los casos de San Isidoro de Dueñas y San Zoilo de Carrión de los Condes son ilustrativos a este respecto. A mi modo de ver habría que añadir

70 La práctica en Sahagún de la liturgia funeraria cluniacense la pone de relieve la cubierta del Alfonso Pérez (ob. 1093) hijo de uno de los nobles más allegados al monarca, Pedro Ansúrez (D. HAssig, "He Will Make Alive Your Mortal Bodies: Cluniac Spirituality and the Tomb of Alfonso Ansúrez", Gesta, XXX/2 (1991), pp. 140-153).

71 O.B. RAder, Tumba y poder. El culto político a los muertos desde Alejandro hasta Lenin, Madrid, 2006 (Munich, 2003), pp. 91-101.

72 Una síntesis de las diferentes hipótesis en torno a que, a partir del relato de Rodrigo Jiménez de Rada sobre Alfonso VI en su De rebus Hispaniae, existiera una épica culta o quizá, más allá de la inconclusa Seminense, una Vita en torno a la figura del monarca: A. DeYermond, La literatura perdida de la Edad Media castellana. Catálogo y estudio. I-Épica y Romances, Salamanca, 1995, pp. 126-127. Aunque nos faltan datos, la presencia de un ciclo pictórico en los muros de la estructura que evocaba la derrota de Uclés (1108) debió introducirse en fechas tardías. El sucinto dato documental de esta ornamentación se encuentra en: J.B. GUARDiola, Historia del monasterio de San Benito el Real de Sahagún (H.S. Martínez, ed.), León, 2007, p. 313). 
la iglesia de San Martín de Frómista como un excepcional derivado de ambos una vez que fue sujeta a la orden en 1118 .

Caso aparte es el del monasterio de los Santos Facundo y Primitivo de Sahagún, institución independiente pero reformada bajo los parámetros cluniacenses a partir de 1080. Contamos con indicios documentales y arqueológicos que hacen pensar en que la basílica primitiva de Alfonso III sobrevivió a la muerte de su homónimo de León-Castilla en 1109. De algún modo este conservacionismo perfilaba las tensiones de la propia sociedad dual que vivió Alfonso VI: la tendencia de un sector autóctono hacia el atavismo y, en el marco de la política gregoriana, las presiones, cada vez más beligerantes, de Roma y de sectores fundamentalmente procedentes de territorio franco en pro de la homologación del territorio con el continente. El añadido a la vieja iglesia prerrománica de una estructura de contenido litúrgico foráneo ilustraba la voluntad del rey de asociar su memoria a las raíces de su legitimidad y, al mismo tiempo ponía de relieve tanto el triunfo de una nueva forma de espiritualidad como el irremediable tránsito hacia la novedosa realidad constructiva que se imponía. Un camino de no retorno que en progresión escalonada fue barriendo con un paisaje monumental que, por los datos con que contamos y salvadas excepciones, en las escasas iniciativas puestas en marcha en la primera mitad del siglo XI respondía a una inercia escasamente original respecto al pasado. 